\title{
The Keys to Optimising Breast Wounds: A Meta-Analysis
}

\author{
Stephanie Mary Anne Vincent ${ }^{1,2}$, Mary Gallagher ${ }^{1,2}$, Alison Johnston1, Risal Djohan ${ }^{3}$, \\ Manvydas Varzgalis ${ }^{1}$, Michael Sugrue ${ }^{1^{*}}$
}

\author{
${ }^{1}$ Department of Breast Surgery, Letterkenny University Hospital, Donegal Clinical Research Academy, Donegal, Ireland \\ ${ }^{2}$ National University of Ireland, Galway, Ireland \\ ${ }^{3}$ Department of Plastic Surgery, Cleveland Clinic, Cleveland, OH, USA \\ Email: *michael.sugrue@hse.ie
}

How to cite this paper: Vincent, S.M.A., Gallagher, M., Johnston, A., Djohan, R., Varzgalis, M. and Sugrue, M. (2019) The Keys to Optimising Breast Wounds: A Meta-Analysis. Advances in Breast Cancer Research, 8, 87-111.

https://doi.org/10.4236/abcr.2019.83007

Received: April 27, 2019

Accepted: June 25, 2019

Published: June 28, 2019

Copyright $\odot 2019$ by author(s) and Scientific Research Publishing Inc. This work is licensed under the Creative Commons Attribution International License (CC BY 4.0).

http://creativecommons.org/licenses/by/4.0/

\begin{abstract}
Background: Breast disease and breast cancer management form a major part of healthcare delivery. Surgical site occurrence (SSO) poses septic and oncological risks to patients. This study undertook a meta-analysis to identify key risk factors and interventions that may alter the incidence of SSO in patients undergoing breast surgery. Methods: An ethically approved, PROSPERO-registered meta-analysis following PRISMA guidelines and Cochrane Handbook for Systematic Reviews was undertaken of all published English articles using electronic databases from 2010 to 2017 incorporating MeSH terms "risk factors", "surgical site infections", "breast surgery", and "interventions". Articles scoring $>10$ for non-comparative studies and $>15$ for comparative studies, using MINORS criteria were included. The OR or RR using random-effects, Mantel-Haenszel method were computed for each risk factor and intervention respectively with RevMan 5 . Results: The pre-operative factors affecting breast surgery SSO were diabetes mellitus $(\mathrm{OR}=2.52, \mathrm{CI}=1.78-3.59, \mathrm{p}<$ $0.001)$, smoking $(\mathrm{OR}=2.39, \mathrm{CI}=1.57-3.63, \mathrm{p}<0.001), \mathrm{ASA} \geq \mathrm{III}(\mathrm{OR}=$ $2.37, \mathrm{CI}=1.51-3.74, \mathrm{p}<0.001)$, obese versus non-obese $(\mathrm{OR}=1.84, \mathrm{CI}=$ $1.52-2.24, \mathrm{p}<0.001)$, over-weight/obese versus normal BMI $(\mathrm{OR}=1.70$, CI $=1.36-2.13, \mathrm{p}<0.001)$, hypertension $(\mathrm{OR}=1.63, \mathrm{CI}=1.39-1.90, \mathrm{p}<$ $0.001)$, and antibiotics prophylaxis $(\mathrm{RR}=0.58, \mathrm{CI}=0.36-0.95, \mathrm{p}=0.03)$. The intraoperative factors were surgical wound classifications $3-4(\mathrm{OR}=6.16, \mathrm{CI}$ $=2.52-15.02, \mathrm{p}<0.001)$, surgical drains $(\mathrm{OR}=2.80, \mathrm{CI}=1.06-7.38, \mathrm{p}=$ $0.04)$, and axillary lymph node dissection $(\mathrm{OR}=1.46, \mathrm{CI}=1.18-1.80, \mathrm{p}<$ $0.001)$. The post-operative factors were adjuvant radiotherapy $(\mathrm{OR}=1.77, \mathrm{CI}$ $=1.26-2.50, \mathrm{p}=0.001)$, re-operated patients $(\mathrm{OR}=1.65, \mathrm{CI}=1.01-2.70, \mathrm{p}=$ $0.05)$, post-operative antibiotics $(\mathrm{RR}=0.57, \mathrm{CI}=0.33-0.98, \mathrm{p}=0.04)$, and drain antisepsis care $(R R=0.15, C I=0.03-0.82, p=0.03)$. Conclusions:
\end{abstract}


This study identified key factors associated with increased risk of breast surgery wound occurrence. It will facilitate the development of a peri-operative breast wound bundle to optimize outcomes.

\section{Keywords}

Breast Wound Care, Breast Wound Infection, Breast Surgical Site, Adverse Outcomes, Breast Implant Loss, Return to the Operating Theatre

\section{Introduction}

Breast disease and breast cancer management form a major part of healthcare delivery, constituting one of the most frequent elective surgeries performed globally [1]. Uncomplicated surgical outcomes are important in optimising functional, cosmetic and oncological outcomes. Surgical site occurrence (SSO) including wound infection, wound dehiscence and deep infection, with or without implant loss pose septic and oncological risks to patients [2] [3] [4]. There is a spectrum from minor wound infection to implant loss with increasing costs for the health care system [3] [5]. Reducing SSO will benefit patient's physical and psychological outcomes, facilitate adjuvant treatment, and optimise long term cosmetic and oncological outcomes [6] [7].

Wound infection and adverse wound events are multifactorial [8] [9] [10]. Identifying the relative importance of the contributing factors is challenging. A bundle approach to wound care has been shown to facilitate better outcomes [11] [12] [13]. There are few reports of the use of bundled approaches to reducing SSO in breast surgery [14]. The National Mastectomy Audit suggests that current rates of SSO are unacceptable [15].

The aim of this meta-analysis is to identify key risk factors and interventions that may alter the incidence of SSO in patients undergoing breast surgery.

\section{Methods}

\subsection{Search Strategy and Study Eligibility}

An ethically approved meta-analysis of the literature was undertaken to incorporate articles relating to breast wound care, breast wound infection, breast surgical site adverse outcomes, infected related implant loss, and return to the operating theatre. Existing research optimising wound care in surgery was reviewed to determine current strategies to improve wound outcomes. Key risk factors and interventions for SSO were identified in three keys phases of care, pre-, intra- and post-operative periods.

The methods of analysis and inclusion criteria were specified in advance to avoid selection bias and documented in a protocol which was registered and published with the International Prospective Register of Systematic Reviews (PROSPERO) (ID 42016039883). This meta-analysis adhered to the Preferred 
Reporting Items for Systematic Reviews and Meta-Analyses (PRISMA) statement [16] and Cochrane Handbook for Systematic Reviews of Interventions [17].

A systematic review and meta-analysis of all published English articles was conducted using PubMed, Scopus and Cochrane Library electronic databases from 2010 to 2017. Medical Subject Headings used terms which included risk factors ("risk factor ${ }^{\star ”), ~ s u r g i c a l ~ s i t e ~ i n f e c t i o n s ~(" s u r g i c a l ~ s i t e ~ i n f e c t i o n " ~}{ }^{\star ”, ~ " w o u n d ~}$ infection" ${ }^{\star ”), ~ b r e a s t ~ s u r g e r y ~(" b r e a s t ~ s u r g ~}{ }^{\star ”), ~ a n d ~ i n t e r v e n t i o n s ~(" i n t e r v e n t i o n " ~}{ }^{\star ”) . ~}$ The following search strategies were used in our meta-analysis: ("risk factor" AND "breast surg*" AND “infection*”), ("intervention*" AND "breast surg ${ }^{\star » " ~}$ AND "infection*"), ("risk factor ${ }^{\star}$ ” OR “intervention*” AND "breast surg ${ }^{\star ” ~ A N D ~}$ "surgical site infection"), and ("risk factor ${ }^{\star}$ " OR "intervention" AND "breast $\operatorname{surg}^{\star}$ " AND "wound infection*"). Studies that were case studies or meta-analysis, not related to breast surgery, did not report key outcomes, or where data was inadequate for interpretation via meta-analysis, or duplicate studies were excluded.

Eligibility assessment was performed independently in a blinded standardised manner by two reviewers (SV and MG). Disagreements between reviewers were resolved by discussion between the two review authors and if no agreement could be reached, it was planned a third reviewer (AJ) would decide.

\subsection{Data Extraction and Quality Assessment}

We developed a standardised data extraction sheet and one reviewer (SV) extracted the following data from included studies and the second reviewer (MG) checked the extracted data. Discrepancies were resolved by discussion and consultation with another reviewer (AJ). Two reviewers (SV and MG) independently assessed each published study for the quality of study design by using the Methodological Index for Nonrandomised Studies (MINORS) score whereby the global ideal score is 16 for non-comparative studies and 24 for comparative studies [18]. Articles scoring $>10$ for non-comparative studies and $>15$ for comparative studies, using MINORS criteria were included in the final analysis (Table S1). Risk of bias across studies was not assessed as there were too few included studies per outcome.

Information was extracted from each included study on: 1) Characteristics of participants 2) Inclusion and exclusion criteria 3) Risk factor or type of intervention 4) Well-reported outcome measurements (including a clear report of surgical site infections or breast wound infections).

\subsection{Data Synthesis and Analysis}

The odds ratio (OR) and risk ratio (RR) of surgical site infections (SSI) were the primary measure of risk factors and intervention effect respectively. The meta-analyses were performed by computing the OR or RR using Mantel-Haenszel method and random-effects model to combine variables of interest. OR or RR 
and 95\% Confidence Intervals (CI) for each risk factor and intervention were calculated. No additional analyses were done. The analysis was performed by using Review Manager Version 5 [19].

\subsection{Definitions}

The Centres for Disease Control and Prevention (CDC) definitions [5] [20] for surgical site infection were used. These are classified into superficial, deep or organ/space relating to implant/infection. The ASEPSIS (Additional treatment, Serous discharge, Erythema, Purulent exudate, Separation of deep tissues, Isolation of bacteria, Stay duration as inpatient $>14$ days) scoring system was also used to quantify surgical site infections [21].

WHO classification of nutritional status according to Body Mass Index (BMI) [22] was used to categorise underweight (BMI < 18.5), normal weight (BMI 18.5 - 24.9), pre-obesity (BMI 25.0 - 29.9), obesity class 1 (BMI 30.0 - 34.9), obesity class 2 (BMI 35.0 - 39.9), and obesity class 3 (BMI > 40). Patients were considered to have diabetes mellitus only if they were taking oral hypoglycaemic agents and/or on insulin. Patients were considered smokers if they were currently smokers or had smoked cigarettes in the year before admission for surgery. The tumour-node-metastasis (TNM) classification [23] for breast cancer was used to determine breast cancer staging. The American Society of Anesthesiology (ASA) Physical Status classification [24] was defined as follows: 1) normal healthy patient; 2) mild systemic disease; 3) patient with severe systemic disease; 4) severe systemic disease with constant threat to life; and 5) moribund patient not expected to survive without surgery. Neoadjuvant chemotherapy treatment was defined as administration of chemotherapeutic agents for cancer within 30 to 90 days prior to surgery [28] [33] [34] [40] [57] [61] [65]. Neoadjuvant radiotherapy included patients who had treatment within 90 days before surgery. Breast reoperations were defined as re-excision or mastectomy within 180 days of initial breast surgery.

To determine the level of risk, a number of classification systems were used in this study. These included the surgical wound classification [5] [20] and the National Nosocomial Infection Surveillance (NNIS) Risk Index [25].

\section{Results}

This meta-analysis reviewed 1606 articles for risk factors and interventions of SSI in breast surgery. 64 studies were found to be suitable after eligibility analysis and 49 studies were included for quantitative analysis of this meta-analysis (Figure 1). Characteristics of the studies included in this meta-analysis are listed in Table S2. Significant and insignificant factors affecting breast SSO that are not included in the quantitative meta-analysis are listed in Table 1 and Table 2 respectively.

A number of statistical significant causative factors and interventions for SSI in breast surgery in the key phases of care were identified; seven in pre-operative, three in intra-operative and four in post-operative. 
S. M. A. Vincent et al.

Table 1. Significant factors for breast SSO not included in the quantitative meta-analysis.

\begin{tabular}{|c|c|c|c|c|}
\hline Study ID & Significant factors & $\begin{array}{l}\text { Odds } \\
\text { Ratio }\end{array}$ & $95 \% \mathrm{CI}$ & p-value \\
\hline & Pre-operative phase & & & \\
\hline Angarita 2011 [26] & Active skin disorders & 36.39 & $7.76-173.45$ & $<0.001$ \\
\hline \multirow[t]{2}{*}{ Chung 2015 [30] } & Hypertension & 1.82 & $1.41-2.33$ & $<0.001$ \\
\hline & Pulmonary comorbidity & 4.29 & $1.43-12.82$ & 0.009 \\
\hline \multirow[t]{6}{*}{ Olsen 2016 [57] } & Depression & 1.62 & $1.17-2.24$ & 0.004 \\
\hline & Obesity & 1.85 & $1.35-2.54$ & $<0.001$ \\
\hline & Liver disease & 4.07 & $1.71-9.73$ & 0.002 \\
\hline & Tobacco use disorder & 1.29 & $1.00-1.67$ & 0.05 \\
\hline & Smoking related disorder & 2.22 & $1.52-3.24$ & $<0.001$ \\
\hline & Rheumatologic disease & 1.86 & $1.10-3.13$ & 0.02 \\
\hline Ota 2016 [60] & $\mathrm{BMI} \geq 25$ & 4.79 & $1.64-13.97$ & 0.004 \\
\hline Pettke 2016 [87] & Age $\geq 80$ years & 0.66 & $0.57-0.78$ & $<0.001$ \\
\hline \multirow[t]{2}{*}{ Tanner 2011 [67] } & NNIS score 1 & 3.97 & $1.16-13.54$ & 0.03 \\
\hline & NNIS score 2 & 33.75 & $4.34-262.28$ & $<0.001$ \\
\hline Teija-Kaisa 2012 [68] & $\begin{array}{l}\text { AMP } 30 \text { - } 60 \text { mins before incision } \\
\text { Intra-operative phase }\end{array}$ & 2.64 & $1.05-6.65$ & 0.04 \\
\hline Angarita 2011 [26] & Radical vs BCS & 17.62 & $5.13-60.47$ & $<0.001$ \\
\hline Chattha 2017 [75] & Mastectomy weight $\geq 500 \mathrm{~g}$ & 2.98 & $1.78-5.01$ & $<0.001$ \\
\hline \multirow[t]{2}{*}{ Cordeiro 2016 [77] } & Overnight stay vs same-day stay & 1.48 & $1.24-1.76$ & $<0.001$ \\
\hline & Stay $\geq 2$ days vs same-day stay & 2.16 & $1.79-2.61$ & $<0.001$ \\
\hline Franchelli 2012 [40] & Tumour stage II-IV & 5.29 & $1.35-20.66$ & 0.02 \\
\hline Gil-Londoño 2017 [80] & Radical mastectomy & 2.73 & $1.43-5.19$ & 0.002 \\
\hline Gülçelık 2017 [83] & IORT & 12.97 & $1.57-107.18$ & 0.02 \\
\hline Olsen 2015 [56] & Needle localisation & 0.78 & $0.66-0.92$ & 0.003 \\
\hline Parikh 2016 [85] & $\begin{array}{l}\text { Ambulatory surgery } \\
\text { centre vs outpatient }\end{array}$ & 0.35 & $0.28-0.44$ & $<0.001$ \\
\hline \multirow[t]{2}{*}{ Winocour 2015 [72] } & Operative time $\geq 2.5$ hours & 2.19 & $1.72-2.80$ & $<0.001$ \\
\hline & Post-operative phase & & & \\
\hline Franchelli 2012 [40] & $\begin{array}{l}\text { Radiotherapy after surgery } \\
\text { before infection }\end{array}$ & 4.08 & $1.03-16.23$ & 0.05 \\
\hline \multirow[t]{3}{*}{ Leyngold 2012 [49] } & Cellulitis & 242.67 & $35.42-1662.23$ & $<0.001$ \\
\hline & Wound dehiscence & 10.06 & $2.65-38.27$ & $<0.001$ \\
\hline & Wound necrosis & 8.74 & $2.32-32.95$ & $<0.001$ \\
\hline Olsen 2016 [57] & Home healthcare & 0.72 & $0.58-0.89$ & 0.002 \\
\hline Olsen 2017 [58] & SSI after SR + Implant IR & 4.58 & $3.23-6.50$ & $<0.001$ \\
\hline Ota 2016 [60] & Seroma aspiration & 15.92 & $6.16-41.11$ & $<0.001$ \\
\hline Pellino 2014 [86] & NPWT & 0.22 & $0.05-0.93$ & 0.04 \\
\hline
\end{tabular}


Table 2. Insignificant factors for breast SSO not included in the quantitative meta-analysis.

\begin{tabular}{|c|c|c|c|c|}
\hline Study ID & Insignificant factors & $\begin{array}{l}\text { Odds } \\
\text { Ratio }\end{array}$ & $95 \% \mathrm{CI}$ & p-value \\
\hline & Pre-operative phase & & & \\
\hline Chung 2015 [30] & Alcohol use & 1.71 & $0.39-7.41$ & 0.48 \\
\hline Leyngold 2012 [49] & Age $>60$ years & 0.44 & $0.05-3.62$ & 0.45 \\
\hline \multirow[t]{5}{*}{ Olsen 2016 [57] } & Age 51 - 64 years & 1.05 & $0.89-1.24$ & 0.57 \\
\hline & Rural vs urban residence & 1.2 & $0.95-1.50$ & 0.12 \\
\hline & 0 - 50th income quartile & 1.01 & $0.85-1.20$ & 0.92 \\
\hline & Previous radiotherapy & 1.17 & $0.82-1.68$ & 0.38 \\
\hline & Inflammatory breast disease & 1.57 & $0.88-2.83$ & 0.13 \\
\hline \multirow[t]{4}{*}{ Teija-Kaisa 2012 [68] } & Age $\geq 65$ & 0.64 & $0.36-1.12$ & 0.12 \\
\hline & Pre-operative hospital stay $\geq 48 \mathrm{hrs}$ & 1.22 & $0.07-22.34$ & 0.89 \\
\hline & Non-intact skin condition & 0.67 & $0.38-1.19$ & 0.17 \\
\hline & Intra-operative phase & & & \\
\hline Cooney 2016 [76] & Matching procedure & 1.37 & $0.97-1.95$ & 0.08 \\
\hline Franchelli 2012 [40] & TNM cancer stage II-IV & 2.77 & $0.69-12.71$ & 0.19 \\
\hline Leyngold 2012 [49] & Mastectomy & 1.72 & $0.09-32.72$ & 0.72 \\
\hline Olsen 2015 [56] & Brachytherapy catheter placement & 1.42 & $0.75-2.68$ & 0.28 \\
\hline Olsen 2017 [58] & Implant vs autologous IR & 0.9 & $0.76-1.07$ & 0.24 \\
\hline \multirow[t]{2}{*}{ Ota 2016 [60] } & Excisional biopsy & 1.05 & $0.37-2.98$ & 0.92 \\
\hline & Simultaneous bilateral reconstruction & 0.33 & $0.02-5.79$ & 0.45 \\
\hline Tanner $2011[67]$ & WLE + marker & 1.84 & $0.52-6.52$ & 0.35 \\
\hline \multirow[t]{2}{*}{ Teija-Kaisa 2012 [68] } & Invasive tumour marking & 0.96 & $0.57-1.63$ & 0.89 \\
\hline & Duration of operation $\geq 87$ mins & 1.5 & $0.88-2.55$ & 0.14 \\
\hline Giordano 2013 [81] & $\begin{array}{l}\text { Combination of povidone-iodine } \\
\text { solution }+ \text { antibiotic pocket irrigation }\end{array}$ & 0.67 & $0.11-3.94$ & 0.65 \\
\hline Golfam 2011 [82] & $100 \%$ oxygen & 0.2 & $0.01-4.08$ & 0.3 \\
\hline Mittal 2017 [84] & Harmonic scalpel vs electrocautery & 0.75 & $0.30-1.85$ & 0.63 \\
\hline \multirow[t]{2}{*}{ Williams 2011 [89] } & Triclosan coated sutures & 0.66 & $0.32-1.37$ & 0.27 \\
\hline & Post-operative phase & & & \\
\hline de Oliveira 2014 [78] & Active exercise & 1.2 & $0.60-2.41$ & 0.6 \\
\hline Dieterich 2013 [79] & Hydroxyethyl starch & 0.89 & $0.46-1.73$ & 0.73 \\
\hline Santosa 2016 [88] & $\begin{array}{l}\text { Postmastectomy radiation therapy } \\
\text { before exchange (TE radiotherapy) vs } \\
\text { after permanent implant exchange }\end{array}$ & 0.74 & $0.29-1.91$ & 0.53 \\
\hline
\end{tabular}




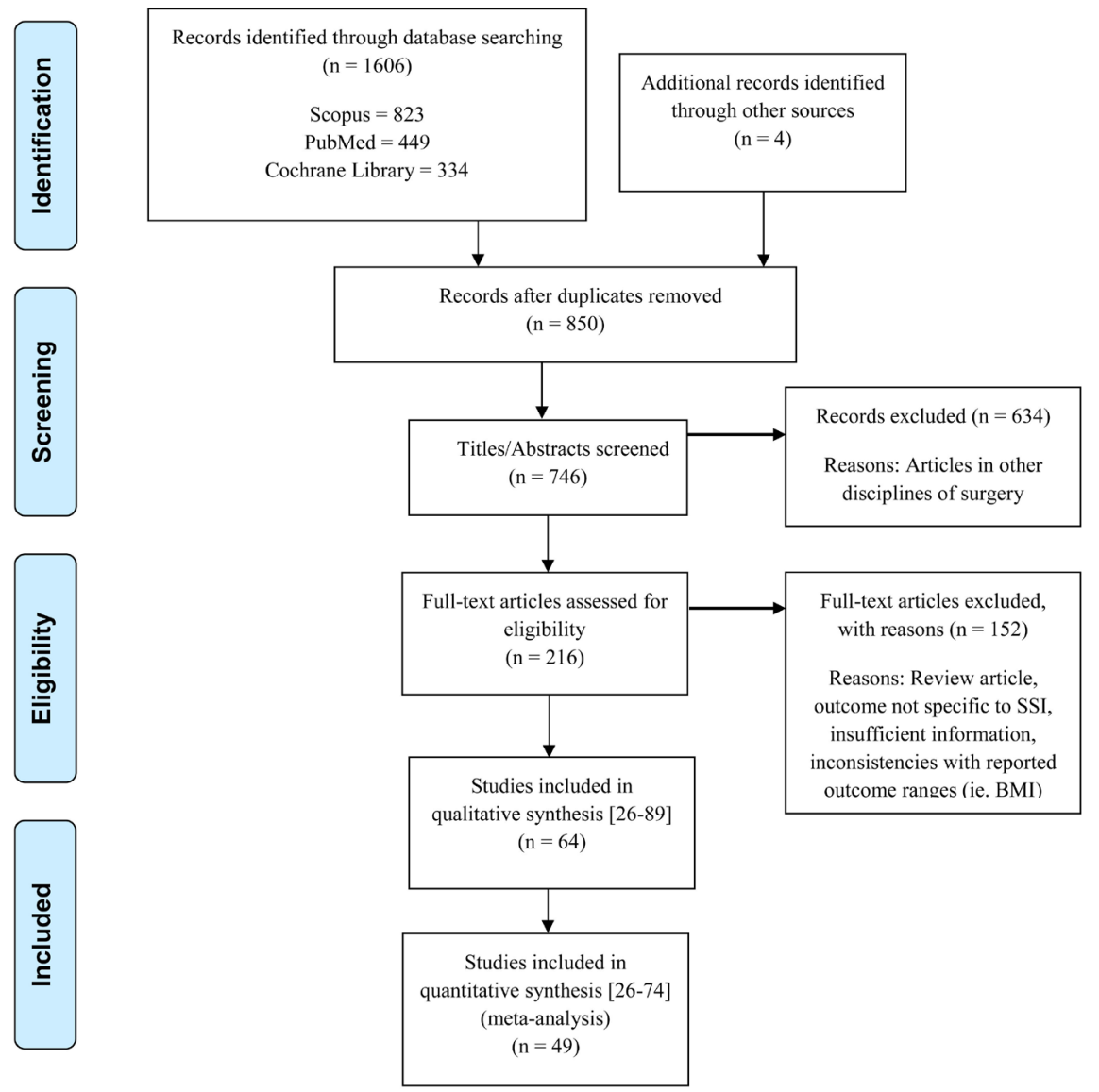

Figure 1. Prisma flow diagram.

\subsection{Pre-Operative Phase}

Significant pre-operative risk factors (Figure 2 and Figure 3) for developing SSI in breast wounds are class 3 obesity versus non-obese $(\mathrm{OR}=2.90, \mathrm{CI}=2.10$ 3.99, $\mathrm{p}<0.001)$, diabetes mellitus $(\mathrm{OR}=2.52, \mathrm{CI}=1.78-3.59, \mathrm{p}<0.001)$, smoking ( $\mathrm{OR}=2.39, \mathrm{CI}=1.57-3.63, \mathrm{p}<0.001)$, American Society of Anesthesiologists (ASA) Physical Status classification $\geq \mathrm{III}(\mathrm{OR}=2.37, \mathrm{CI}=1.51$ $3.74, \mathrm{p}<0.001)$, class 2 obesity versus non-obese $(\mathrm{OR}=1.70, \mathrm{CI}=1.07-2.70$, $\mathrm{p}=0.03)$, class 1 obesity when compared to non-obese and normal BMI respectively $(\mathrm{OR}=1.61, \mathrm{CI}=1.40-1.86, \mathrm{p}<0.001 ; \mathrm{OR}=1.93, \mathrm{CI}=1.59-2.35, \mathrm{p}$ $<0.001)$, overweight versus normal $\mathrm{BMI}(\mathrm{OR}=1.66, \mathrm{CI}=1.15-2.40, \mathrm{p}=$ 0.007 ), and hypertension ( $\mathrm{OR}=1.63, \mathrm{CI}=1.39-1.90, \mathrm{p}<0.001)$. Overall, being overweight or obese versus normal $\mathrm{BMI}$ and being obese versus non-obese was significant for increasing the incidence of SSI $(\mathrm{OR}=1.70, \mathrm{CI}=1.36-2.13$, $\mathrm{p}<0.001 ; \mathrm{OR}=1.84, \mathrm{CI}=1.52-2.24, \mathrm{p}<0.001$ respectively). Interventions shown to be statistically significant in reducing surgical site infections in breast surgery (Figure 6) is antibiotics prophylaxis $(\mathrm{RR}=0.58, \mathrm{CI}=0.36-0.95$, $\mathrm{p}=0.03)$.

Insignificant pre-operative risk factors are neoadjuvant radiotherapy $(\mathrm{OR}=$ $1.26, \mathrm{CI}=0.55-2.89, \mathrm{p}=0.58)$, neoadjuvant chemotherapy $(\mathrm{OR}=0.96, \mathrm{CI}=$ 


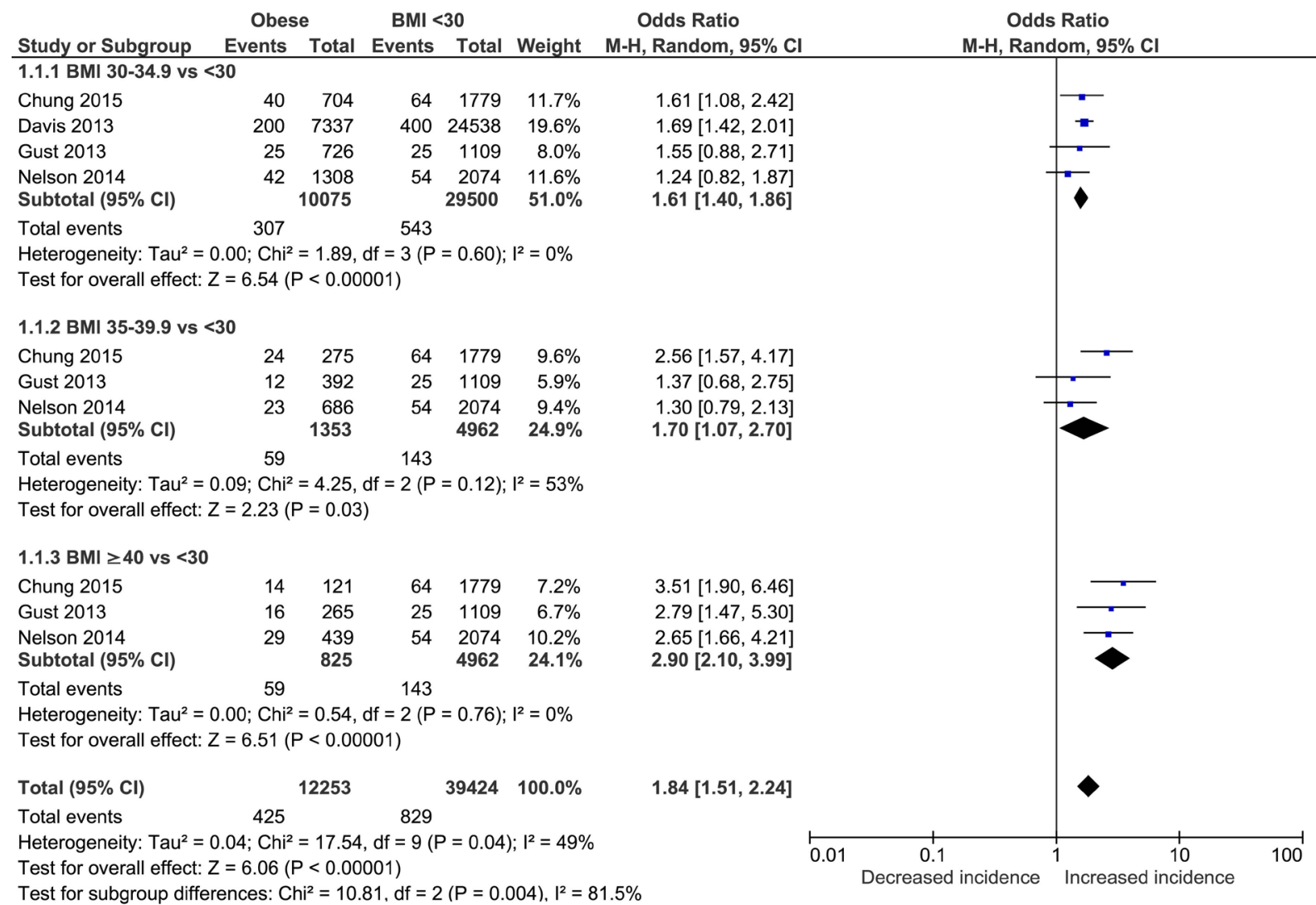

(a)

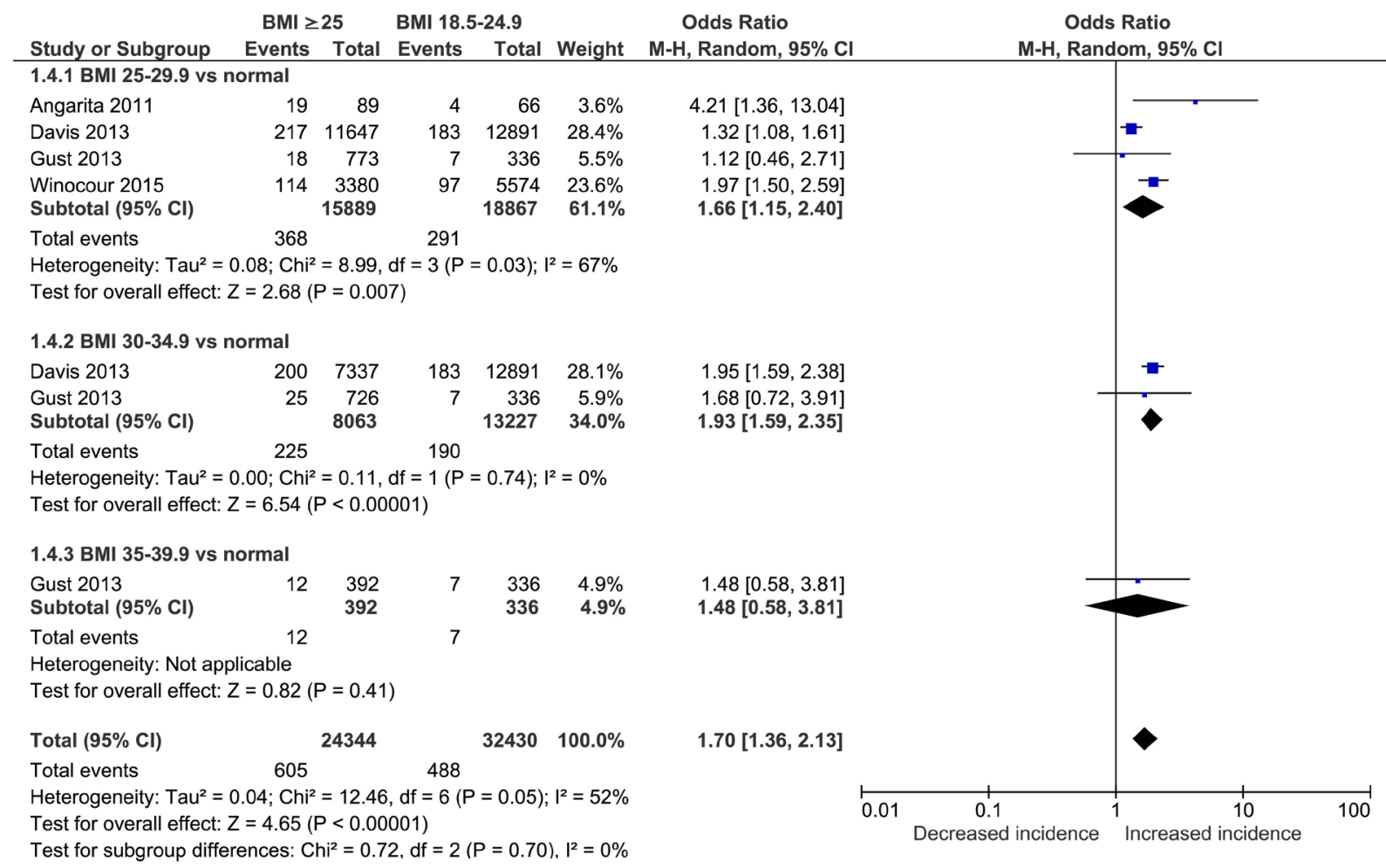

(b)

Figure 2. (a) Obese vs non obese; (b) Overweight/obese vs normal. 


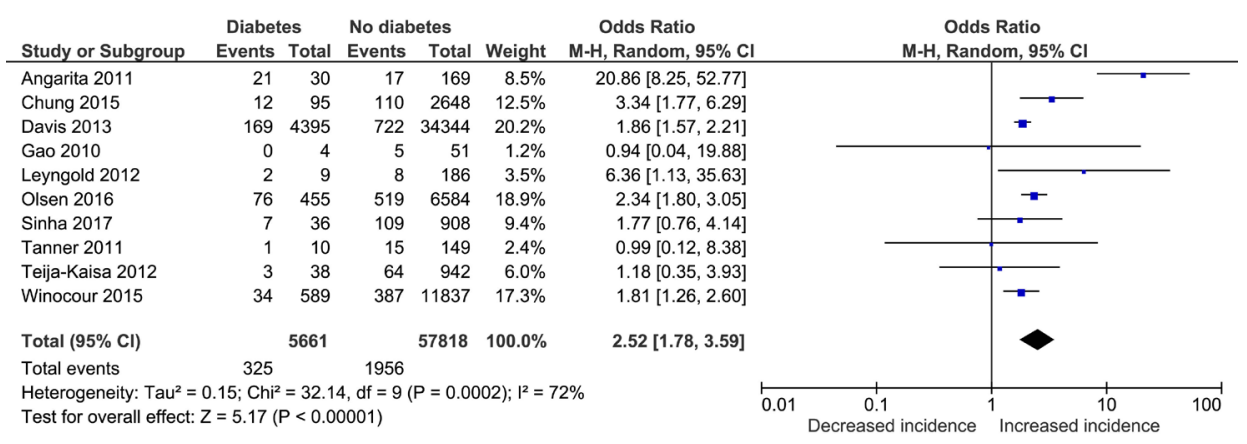

(a)

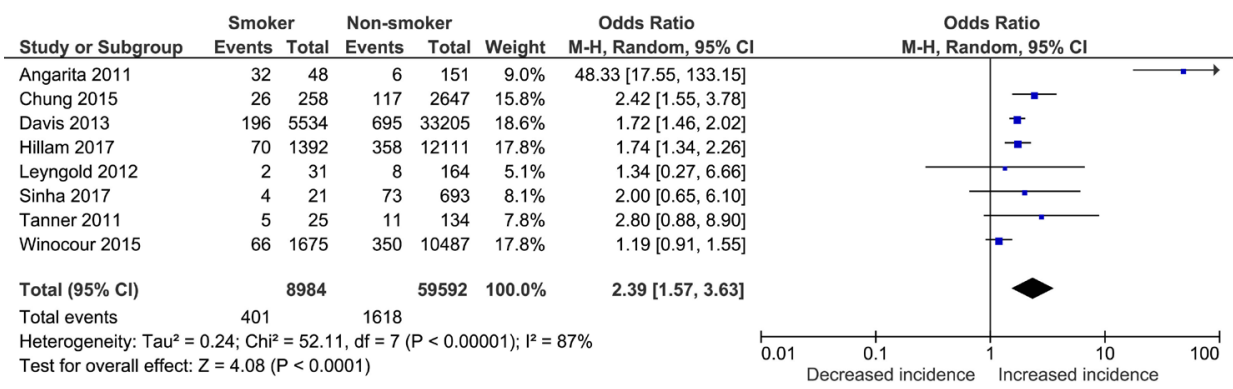

(b)

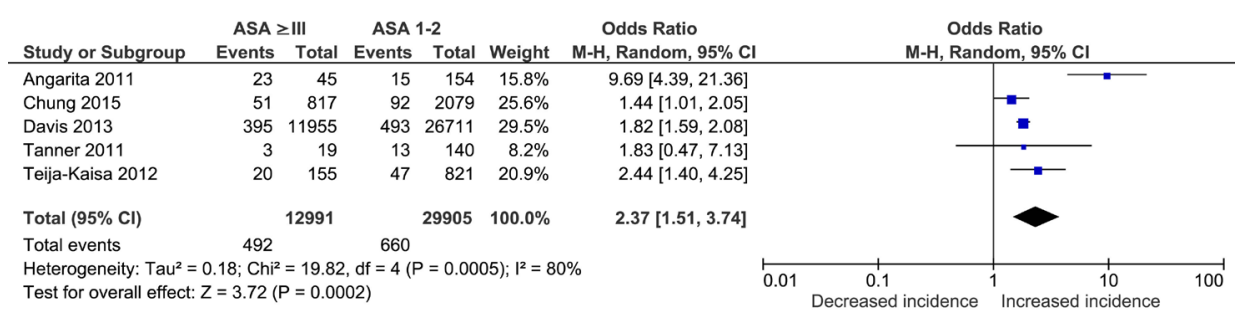

(c)

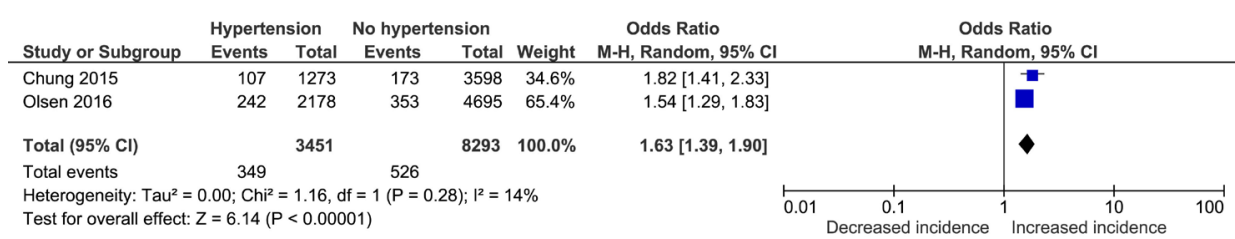

(d)

Figure 3. (a) Diabetes; (b) Smoking; (c) ASA; (d) Hypertension.

$0.84-1.10, \mathrm{p}=0.55)$, age $\geq 50$ years old $(\mathrm{OR}=1.26, \mathrm{CI}=0.97-1.64, \mathrm{p}=0.09)$ and steroids use $(\mathrm{OR}=1.04, \mathrm{CI}=0.81-1.32, \mathrm{p}=0.78)$. Hair removal $(\mathrm{RR}=1.26$, $\mathrm{CI}=0.46-3.44, \mathrm{p}=0.66$ ) was not shown to be statistically significant in reducing breast SSI.

\subsection{Intra-Operative Phase}

Significant intra-operative risk factors (Figure 4) are surgical wound classifications 3 or $4(\mathrm{OR}=6.16, \mathrm{CI}=2.52-15.02, \mathrm{p}<0.001)$, the use of surgical drains $(\mathrm{OR}=2.80, \mathrm{CI}=1.06-7.38, \mathrm{p}=0.04)$, and axillary lymph node dissection $(\mathrm{ALND})(\mathrm{OR}=1.46, \mathrm{CI}=1.18-1.80, \mathrm{p}<0.001)$. 


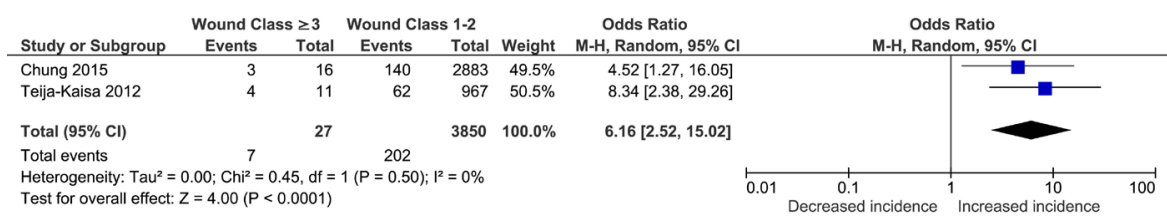

(a)

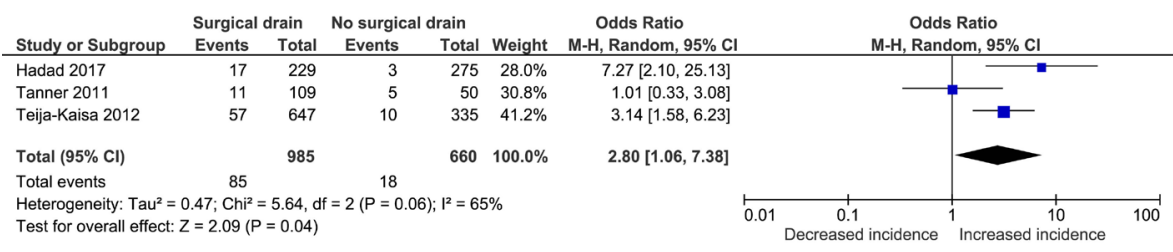

(b)

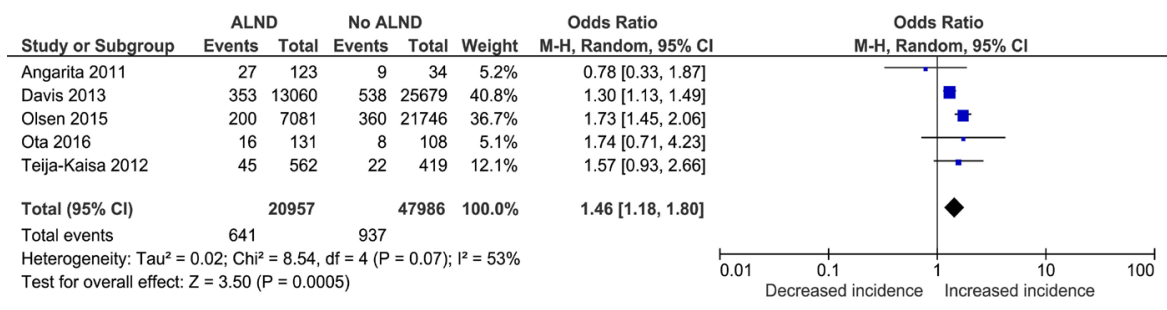

(c)

Figure 4. (a) Surgical wound class; (b) Surgical drains; (c) ALND.

Insignificant intra-operative risk factors are inpatient admission $(\mathrm{OR}=3.59$, $\mathrm{CI}=0.18-72.11, \mathrm{p}=0.40)$, operative time $>2$ hours $(\mathrm{OR}=2.87, \mathrm{CI}=0.32$ $25.47, \mathrm{p}=0.34$ ), immediate breast reconstruction (IBR) versus mastectomy only $(\mathrm{OR}=2.66, \mathrm{CI}=0.72-9.83, \mathrm{p}=0.14)$, IBR versus delayed reconstruction $(\mathrm{OR}=$ $1.39, \mathrm{CI}=0.73-2.64, \mathrm{p}=0.32)$, a cellular dermal matrix $(\mathrm{ADM})$ use $(\mathrm{OR}=1.32$, $\mathrm{CI}=0.22-8.06, \mathrm{p}=0.06)$, breast cancer stage II - IV versus breast cancer stage 0 - $\mathrm{I}(\mathrm{OR}=1.24, \mathrm{CI}=0.54-2.88, \mathrm{p}=0.61)$, breast cancer versus prophylactic stage $(\mathrm{OR}=1.10, \mathrm{CI}=0.82-1.47, \mathrm{p}=0.53)$, and sentinel lymph node biopsy (SLNB) $(\mathrm{OR}=0.46, \mathrm{CI}=0.06-3.57, \mathrm{p}=0.46)$.

\subsection{Post-Operative Phase}

Adjuvant radiotherapy $(\mathrm{OR}=1.77, \mathrm{CI}=1.26-2.50, \mathrm{p}=0.001)$ and re-operated patients $(\mathrm{OR}=1.65, \mathrm{CI}=1.01-2.70, \mathrm{p}=0.05)$ are significant post-operative risk factors (Figure 5). Interventions shown to be statistically significant in reducing surgical site infections in breast surgery (Figure 6) are post-operative antibiotics $(\mathrm{RR}=0.57, \mathrm{CI}=0.33-0.98, \mathrm{p}=0.04)$, and drain antisepsis care $(\mathrm{RR}=0.15, \mathrm{CI}=$ $0.03-0.82, \mathrm{p}=0.03)$.

Adjuvant chemotherapy $(\mathrm{OR}=1.98, \mathrm{CI}=0.97-4.06, \mathrm{p}=0.06)$ was found to be an insignificant postoperative risk factor for breast SSI. Duration of postoperative antibiotics $\geq 24$ hours versus $<24$ hours $(\mathrm{RR}=0.75, \mathrm{CI}=0.51-1.10, \mathrm{p}$ $=0.14)$ and the administration of antibiotics until drain removal versus antibiotics for 24 hours $(\mathrm{RR}=1.00, \mathrm{CI}=0.56-1.80, \mathrm{p}=0.99)$ were not shown to be statistically significant in reducing SSI in breast surgery. 


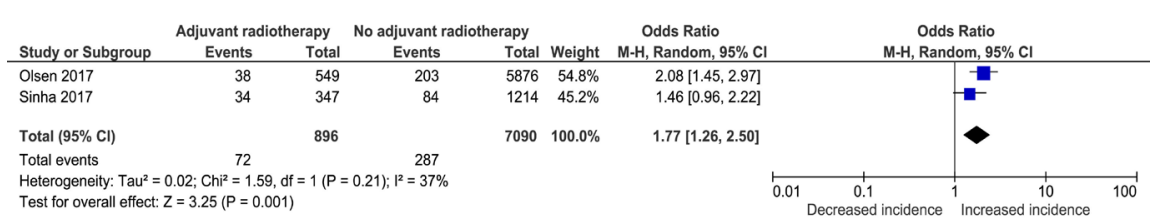

(a)

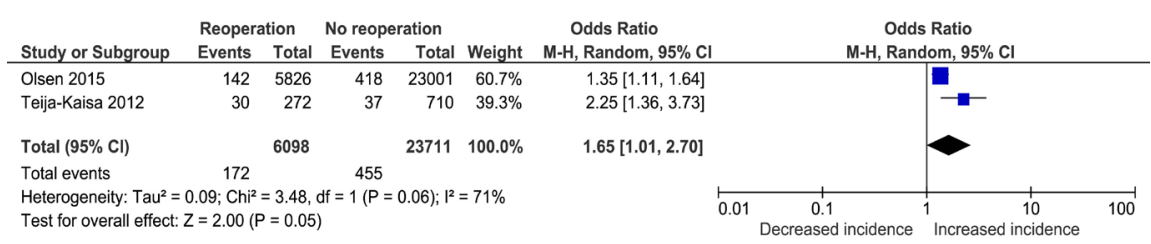

(b)

Figure 5. (a) Adjuvant radiotherapy; (b) Reoperation.

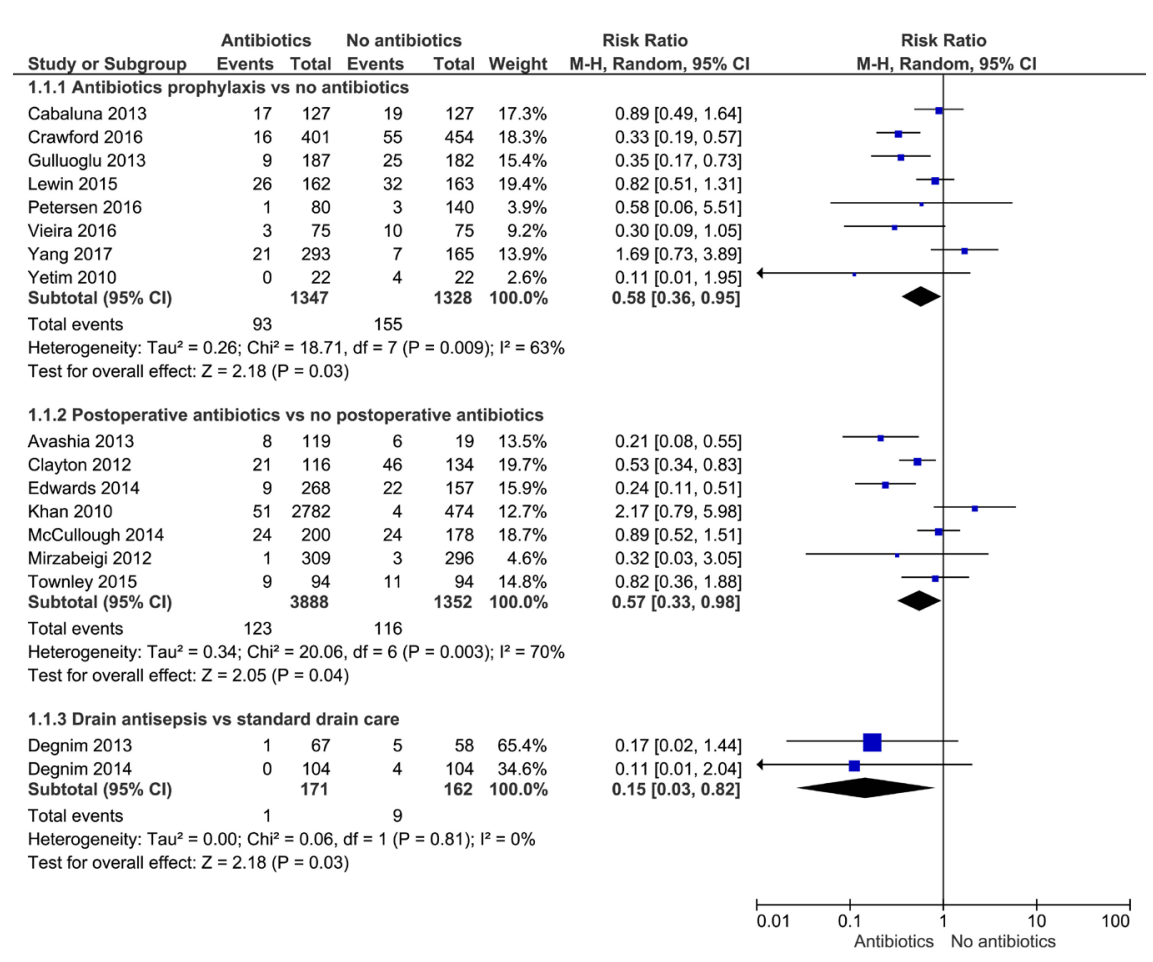

Figure 6. Antibiotics vs none.

\section{Discussion}

This meta-analysis identifies a number of peri-operative factors associated with adverse wound outcomes. Given the volume of breast surgery, both benign and malignant, reduction of adverse wound outcomes is vital; particularly SSO. The importance of preventing SSO is critical in patients having breast surgery (mastectomy) with reconstruction using alloplastic (implant) material and anticipated to have adjuvant chemotherapy and/or radiation treatment. In patients having SSO, their outcome can be compromised as the timing to proceed with necessary chemotherapy or radiation could be delayed, with potential reduction on survival. 
Defining and collecting surgical site infection data is somewhat problematic. There have been many reviews of the nomenclature of wound complications. Terms such as surgical site occurrence (SSO) were introduced in 2010 [90]. Current definitions of SSO are subject to debate in many areas of surgery. The standardized definition of an SSI, developed by the Centres for Disease Control and Prevention (CDC), is an infection occurring in part of the body where surgery took place, including superficial, deep, and organ space infection [5]. It has been suggested that some SSIs are not relevant and in an effort to add more transparency, the term "surgical site occurrences requiring procedural interventions" (SSOPI) has been introduced recently [91]. Another term that has been used is "surgical site event" [92].

Post-operative breast surgery infections even when delayed, or initially thought to be indolent, can be devastating with implant loss or delays in adjuvant treatment. Recently it has been suggested that SSIs following breast cancer surgery decrease oncological survival [3] [93], while others do not support this [94] [95].

Disregarding considerations regarding the reliability of definitions and surveillance, it is clear that understanding risk factors for infection is crucial to preventing SSO and optimising care. The cost of SSI after breast surgery was reported at $\$ 4091$ by one study [96]. The care bundle is not a novel concept, but it is integral for the provision of a team-based approach to patient care. The risk factors identified by this study were grouped into pre-operative, operative and post-operative, which may aid in a tailored approach to intervention.

Patient factors such as obesity and the degree of obesity, smoking, diabetes, recent surgery, and anaesthetic risk will significantly increase the SSI risk. The Breast Care team needs to consider these factors while initially tailoring an optimal surgical strategy and even consider modifying the use of implant based reconstruction in these high-risk patients.

Neo-adjuvant chemotherapy is increasingly used and is not associated with an increased SSI risk.

\section{Conclusion}

This meta-analysis has identified significant risk factors for developing breast related adverse surgical site infections. Planned strategy to mitigate against these should be incorporated into Breast Surgery Care Bundles. Current SSO levels in breast surgery are unacceptably high and need to be addressed. Incorporating wound bundles as key reportable performance indicators or as a mandatory field in oncologist registries may encourage their wider adoption. This may help address concerns expressed about the incidence of wound infection mastectomy [15].

\section{Author Contributions}

M. S., S. V., and A. J. contributed to the idea conception. S. V., M. G., and A. J. 
did the literature search and analysis. S. V., M. S., R. D. and M. V. did the co-writing and editing of the article. S. V., M. G., and A. J. did the statistical analyses and interpretations. M. S., R. D., M.V., S. V., and A. J. did the approval of final article submission.

\section{Ethical Approval}

This study was ethically approved by the Galway University Hospitals Research Ethics Committee.

\section{Fund}

This study was supported by funding from the School of Medicine, National University of Ireland, Galway; Breast Development Fund Letterkenny; and Donegal Clinical Research Academy (DCRA).

\section{Conflicts of Interest}

The authors have no conflicting interests.

\section{References}

[1] Plastic Surgery Statistics Report (2013) American Society of Plastic Surgeons. ASPS National Clearinghouse of Plastic Surgery Procedural Statistics. https://www.plasticsurgery.org/documents/News/Statistics/2013/plastic-surgery-stat istics-full-report-2013.pdf

[2] Beecher, S., O'Leary, D.P., McLaughlin, R. and Kerin, M.J. (2018) The Impact of Surgical Complications on Cancer Recurrence Rates: A Literature Review. Oncology Research and Treatment, 41, 478-482. https://doi.org/10.1159/000487510

[3] Beecher, S.M., O’Leary, D.P., McLaughlin, R., Sweeney, K.J. and Kerin, M.J. (2016) Influence of Complications Following Immediate Breast Reconstruction on Breast Cancer Recurrence Rates. British Journal of Surgery, 103, 391-398. https://doi.org/10.1002/bjs.10068

[4] O’Leary, D.P., Wang, J.H., Cotter, T.G. and Redmond, H.P. (2013) Less Stress, More Success? Oncological Implications of Surgery-Induced Oxidative Stress. Gut, 62, 461-470. https://doi.org/10.1136/gutjnl-2011-300948

[5] Surgical Site Infection (SSI) Event (2016) Centers for Disease Control and Prevention (CDC). http://www.cdc.gov/nhsn/acute-care-hospital/ssi/

[6] Artinyan, A., Orcutt, S.T., Anaya, D.A., Richardson, P., Chen, G.J. and Berger, D.H. (2015) Infectious Postoperative Complications Decrease Long-Term Survival in Patients Undergoing Curative Surgery for Colorectal Cancer: A Study of 12,075 Patients. Annals of Surgery, 261, 497-505. https://doi.org/10.1097/SLA.0000000000000854

[7] Hennigs, A., Biehl, H., Rauch, G., Golatta, M., Tabatabai, P., Domschke, C., et al. (2016) Change of Patient-Reported Aesthetic Outcome Over Time and Identification of Factors Characterizing Poor Aesthetic Outcome after Breast-Conserving Therapy: Long-Term Results of a Prospective Cohort Study. Annals of Surgical Oncology, 23, 1744-1751. https://doi.org/10.1245/s10434-015-4943-Z

[8] Ceppa, E.P., Pitt, H.A., House, M.G., Kilbane, E.M., Nakeeb, A., Schmidt, C.M., et al. (2013) Reducing Surgical Site Infections in Hepatopancreatobiliary Surgery. 
HPB, 15, 384-391. https://doi.org/10.1111/j.1477-2574.2012.00604.x

[9] Dellinger, E.P. (2010) Adherence to Surgical Care Improvement Project Measures: The Whole Is Greater than the Parts. Future Microbiology, 5, 1781-1785.

https://doi.org/10.2217/fmb.10.145

[10] Young, P.Y. and Khadaroo, R.G. (2014) Surgical Site Infections. Surgical Clinics of North America, 94, 1245-1264. https://doi.org/10.1016/j.suc.2014.08.008

[11] Schweizer, M.L., Chiang, H., Septimus, E., Moody, J., Braun, B., Hafner, J., et al. (2015) Association of a Bundled Intervention with Surgical Site Infections among Patients Undergoing Cardiac, Hip, or Knee Surgery. JAMA: The Journal of the American Medical Association, 313, 2162-2171. https://doi.org/10.1001/jama.2015.5387

[12] Johnson, M.P., Kim, S.J., Langstraat, C.L., Jain, S., Habermann, E.B., Wentink, J.E., et al. (2016) Using Bundled Interventions to Reduce Surgical Site Infection after Major Gynecologic Cancer Surgery. Obstetrics \& Gynecology, 127, 1135-1144. https://doi.org/10.1097/AOG.0000000000001449

[13] Featherall, J., Miller, J.A., Bennett, E., et al. (2016) Implementation of an Infection Prevention Bundle to Reduce Surgical Site Infections and Cost Following Spine Surgery. JAMA Surgery, 151, 988-990. https://doi.org/10.1001/jamasurg.2016.1794

[14] Barr, S.P., Topps, A.R., Barnes, N.L., Henderson, J., Hignett, S., Teasdale, R.L., McKenna, A., Harvey, J.R. and Kirwan, C.C. (2016) Northwest Breast Surgical Research Collaborative. Infection Prevention in Breast Implant Surgery-A Review of the Surgical Evidence, Guidelines and a Checklist. European Journal of Surgical Oncology, 42, 591-603. https://doi.org/10.1016/j.ejso.2016.02.240

[15] National Mastectomy and Breast Reconstruction Audit (2011) The NHS Information Centre.

https://www.rcseng.ac.uk/surgeons/research/surgical-research/docs/national-maste ctomy-and-breast-reconstruction-audit-fourth-report-2011

[16] Liberati, A., Altman, D.G., Tetzlaff, J., Mulrow, C., Gøtzsche, P.C., Ioannidis, J.P.A., et al. (2009) The PRISMA Statement for Reporting Systematic Reviews and Meta-Analyses of Studies that Evaluate Health Care Interventions: Explanation and elaboration. PLOS Medicine, 6, e1000100.

https://doi.org/10.1371/journal.pmed.1000100

[17] Higgins, J.P. and Green, S. (2008) Cochrane Handbook for Systematic Reviews of Interventions: Cochrane Book Series. Wiley, New York, 1-649. https://doi.org/10.1002/9780470712184

[18] Slim, K., Nini, E., Forestier, D., Kwiatkowski, F., Panis, Y. and Chipponi, J. (2003) Methodological Index for Non-Randomized Studies (MINORS): Development and Validation of a New Instrument. ANZ Journal of Surgery, 73, 712-716. https://doi.org/10.1046/j.1445-2197.2003.02748.x

[19] Review Manager (RevMan) (2014) Version 5.3. Copenhagen: The Nordic Cochrane Centre, The Cochrane Collaboration.

[20] Garner, J.S. (1985) Guideline for Prevention of Surgical Wound Infections, 1985. Centers for Disease Control and Prevention. http://wonder.cdc.gov/wonder/prevguid/p0000420/p0000420.asp

[21] Wilson, A.P., Treasure, T., Sturridge, M.F. and Grüneberg, R.N. (1986) A Scoring Method (ASEPSIS) for Postoperative Wound Infections for Use in Clinical Trials of Antibiotic Prophylaxis. The Lancet, 327, 311-312.

[22] Body Mass Index-BMI (2019).

http://www.euro.who.int/en/health-topics/disease-prevention/nutrition/a-healthy-li festyle/body-mass-index-bmi 
[23] American Joint Committee on Cancer. (2017) Breast. In: Amin, M.B., Edge, S., Greene, F., Byrd, D.R., Brookland, R.K., et al., Eds., AJCC Cancer Staging Manual, 8th Edition, Springer, New York.

[24] ASA House of Delegates/Executive Committee (2014) ASA Physical Status Classification System. American Society of Anesthesiologists.

[25] Culver, D.H., Horan, T.C., Gaynes, R.P., et al. (1991) Surgical Wound Infection Rates by Wound Class, Operative Procedure, and Patient Risk Index. The American Journal of Medicine, 91, S152-S157. https://doi.org/10.1016/0002-9343(91)90361-Z

[26] Angarita, F.A., Acuna, S.A., Torregrosa, L., Tawil, M., Escallon, J. and Ruíz, T.Á. (2011) Perioperative Variables Associated with Surgical Site Infection in Breast Cancer Surgery. Journal of Hospital Infection, 79, 328-332. https://doi.org/10.1016/j.jhin.2011.08.006

[27] Avashia, Y.J., Mohan, R., Berhane, C. and Oeltjen, J.C. (2013) Postoperative Antibiotic Prophylaxis for Implant-Based Breast Reconstruction with Acellular Dermal Matrix. Plastic and Reconstructive Surgery, 131, 453-461. https://doi.org/10.1097/PRS.0b013e31827c6d90

[28] Bowen, M.E., Mone, M.C., Buys, S.S., Sheng, X. and Nelson, E.W. (2016) Surgical Outcomes for Mastectomy Patients Receiving Neoadjuvant Chemotherapy: A Propensity-Matched Analysis. Annals of Surgery, 265, 448-456. https://doi.org/10.1097/SLA.0000000000001804

[29] Cabaluna, N.D., Uy, G.B., Galicia, R.M., Cortez, S.C., Yray, M.D.S. and Buckley, B.S. (2013) A Randomized, Double-Blinded Placebo-Controlled Clinical Trial of the Routine Use of Preoperative Antibiotic Prophylaxis in Modified Radical Mastectomy. World Journal of Surgery, 37, 59-66.

https://doi.org/10.1007/s00268-012-1816-5

[30] Chung, C.U., Wink, J.D., Nelson, J.A., Fischer, J.P., Serletti, J.M. and Kanchwala, S.K. (2015) Surgical Site Infections after Free Flap Breast Reconstruction: An Analysis of 2899 Patients from the ACS-NSQIP Datasets. Journal of Reconstructive Microsurgery, 31, 434-441. https://doi.org/10.1055/s-0035-1548739

[31] Clayton, J.L., Bazakas, A., Lee, C.N., Scott Hultman, C. and Halvorson, E.G. (2012) Once Is Not Enough: Withholding Postoperative Prophylactic Antibiotics in Prosthetic Breast Reconstruction Is Associated with an Increased Risk of Infection. Plastic and Reconstructive Surgery, 130, 495-502.

https://doi.org/10.1097/PRS.0b013e31825dbefe

[32] Crawford, C.B., Clay, J.A., Seydel, A.S. and Wernberg, J.A. (2016) Surgical Site Infections in Breast Surgery: The Use of Preoperative Antibiotics for Elective, Nonreconstructive Procedures. International Journal of Breast Cancer, 2016, Article ID: 1645192. https://doi.org/10.1155/2016/1645192

[33] Davis, G.B., Peric, M., Chan, L.S., Wong, A.K. and Sener, S.F. (2013) Identifying Risk Factors for Surgical Site Infections in Mastectomy Patients Using the National Surgical Quality Improvement Program Database. The American Journal of Surgery, 205, 194-199. https://doi.org/10.1016/j.amjsurg.2012.05.007

[34] Decker, M.R., Greenblatt, D.Y., Havlena, J., Wilke, L.G., Greenberg, C.C. and Neuman, H.B. (2012) Impact of Neoadjuvant Chemotherapy on Wound Complications after Breast Surgery. Surgery, 152, 382-388. https://doi.org/10.1016/j.surg.2012.05.001

[35] Degnim, A.C., Scow, J.S., Hoskin, T.L., Miller, J.P., Loprinzi, M., Boughey, J.C., et al. (2013) Randomized Controlled Trial to Reduce Bacterial Colonization of Surgical Drains after Breast and Axillary Operations. Annals of Surgery, 258, 240-247. https://doi.org/10.1097/SLA.0b013e31828c0b85 
[36] Degnim, A.C., Hoskin, T.L., Brahmbhatt, R.D., Warren-Peled, A., Loprinzi, M., Pavey, E.S., et al. (2014) Randomized Trial of Drain Antisepsis after Mastectomy and Immediate Prosthetic Breast Reconstruction. Annals of Surgical Oncology, 21, 3240-3248. https://doi.org/10.1245/s10434-014-3918-9

[37] Dikmans, R.E., Negenborn, V.L., Bouman, M.B., Winters, H.A., Twisk, J.W., Ruhé, P.Q., Mureau, M.A., Smit, J.M., Tuinder, S., Eltahir, Y., Posch, N.A., van Steveninck-Barends, J.M., Meesters-Caberg, M.A., van der Hulst, R.R., Ritt, M.J. and Mullender, M.G. (2017) Two-Stage Implant-Based Breast Reconstruction Compared with Immediate One-Stage Implant-Based Breast Reconstruction Augmented with an Acellular Dermal Matrix: An Open-Label, Phase 4, Multicentre, Randomised, Controlled Trial. The Lancet Oncology, 18, 251-258. https://doi.org/10.1016/S1470-2045(16)30668-4

[38] Drury, K.E., Lanier, S.T., Khavanin, N., Hume, K.M., Gutowski, K.A., Thornton, B.P., et al. (2016) Impact of Postoperative Antibiotic Prophylaxis Duration on Surgical Site Infections in Autologous Breast Reconstruction. Annals of Plastic Surgery, 76, 174-179. https://doi.org/10.1097/SAP.0000000000000514

[39] Edwards, B.L., Stukenborg, G.J., Brenin, D.R. and Schroen, A.T. (2014) Use of Prophylactic Postoperative Antibiotics during Surgical Drain Presence Following Mastectomy. Annals of Surgical Oncology, 21, 3249-3255. https://doi.org/10.1245/s10434-014-3960-7

[40] Franchelli, S., Vassallo, F., Porzio, C., Mannucci, M., Priano, V., Schenone, E., et al. (2012) Breast Implant Infections after Surgical Reconstruction in Patients with Breast Cancer: Assessment of Risk Factors and Pathogens over Extended PostOperative Observation. Surgical Infections, 13, 154-158. https://doi.org/10.1089/sur.2011.004

[41] Fraser, V.J., Nickel, K.B., Fox, I.K., Margenthaler, J.A. and Olsen, M.A. (2016) The Epidemiology and Outcomes of Breast Cancer Surgery. Transactions of the American Clinical and Climatological Association, 127, 46-58.

[42] Gao, Y., Xu, L., Ye, J., Wang, D., Zhao, J., Zhang, L., Duan, X. and Liu, Y. (2010) Analysis of Risk Factors of Surgical Site Infections in Breast Cancer. Chinese Medical Journal, 123, 559-562.

[43] Gulluoglu, B.M., Guler, S.A., Ugurlu, M.U. and Culha, G. (2013) Efficacy of Prophylactic Antibiotic Administration for Breast Cancer Surgery in Overweight or Obese patients: A Randomized Controlled Trial. Annals of Surgery, 257, 37-43. https://doi.org/10.1097/SLA.0b013e31826d832d

[44] Gust, M.J., Smetona, J.T., Persing, J.S., Hanwright, P.J., Fine, N.A. and Kim, J.Y.S. (2013) The Impact of Body Mass Index on Reduction Mammoplasty: A Multicenter Analysis of 2492 Patients. Aesthetic Surgery Journal, 33, 1140-1147. https://doi.org/10.1177/1090820X13508131

[45] Hadad, E., Wiser, I., Rosenthal, A., Landau, G., Ziv, E. and Heller, L. (2017) Suction Drains in Esthetic Breast Implant Exchange Are Associated with Surgical Site Infections: A Retrospective Cohort Study. Journal of Plastic, Reconstructive \& Aesthetic Surgery, 70, 1635-1640. https://doi.org/10.1016/j.bjps.2017.06.034

[46] Hillam, J.S., Borsting, E.A., Chim, J.H. and Thaller, S.R. (2017) Smoking as a Risk Factor for Breast Reduction: An Analysis of 13,503 Cases. Journal of Plastic, Reconstructive \& Aesthetic Surgery, 70, 734-740. https://doi.org/10.1016/j.bjps.2016.12.012

[47] Khan, U.D. (2010) Breast Augmentation, Antibiotic Prophylaxis, and Infection: Comparative Analysis of 1,628 Primary Augmentation Mammoplasties Assessing the Role and Efficacy of Antibiotics Prophylaxis Duration. Aesthetic Plastic Surgery, 
34, 42-47. https://doi.org/10.1007/s00266-009-9427-8

[48] Lewin, R., Elander, A., Thorarinsson, A., Kölby, L., Sahlin, P., Lundberg, J., et al. (2015) A Randomized Prospective Study of Prophylactic Cloxacillin in Breast Reduction Surgery. Annals of Plastic Surgery, 74, 17-21. https://doi.org/10.1097/SAP.0000000000000352

[49] Leyngold, M.M., Stutman, R.L., Khiabani, K.T., Shah, H., Fong, E., Ho, C., et al. (2012) Contributing Variables to Post Mastectomy Tissue Expander Infection. The Breast Journal, 18, 351-356. https://doi.org/10.1111/j.1524-4741.2012.01253.x

[50] Liu, A.S., Kao, H., Reish, R.G., Hergrueter, C.A., May Jr., J.W. and Guo, L. (2011) Postoperative Complications in Prosthesis-Based Breast Reconstruction Using Acellular Dermal Matrix. Plastic and Reconstructive Surgery, 127, 1755-1762. https://doi.org/10.1097/PRS.0b013e31820cf233

[51] Liu, D.Z., Dubbins, J.A., Louie, O., Said, H.K., Neligan, P.C. and Mathes, D.W. (2012) Duration of Antibiotics after Microsurgical Breast Reconstruction Does Not Change Surgical Infection Rate. Plastic and Reconstructive Surgery, 129, 362-367. https://doi.org/10.1097/PRS.0b013e31823ae8ce

[52] McCullough, M.C., Chu, C.K., Duggal, C.S., Losken, A. and Carlson, G.W. (2014) Antibiotic Prophylaxis and Resistance in Surgical Site Infection after Immediate Tissue Expander Reconstruction of the Breast. Annals of Plastic Surgery, 77, 501-505.

[53] Mirzabeigi, M.N., Mericli, A.F., Ortlip, T., Tuma, G.A., Copit, S.E., Fox, I.V., et al. (2012) Evaluating the Role of Postoperative Prophylactic Antibiotics in Primary and Secondary Breast Augmentation: A Retrospective Review. Aesthetic Surgery Journal, 32, 61-68. https://doi.org/10.1177/1090820X11430830

[54] Nelson, J.A., Fischer, J.P., Chung, C.U., West, A., Tuggle, C.T., Serletti, J.M., et al. (2014) Obesity and Early Complications Following Reduction Mammoplasty: An Analysis of 4545 Patients from the 2005-2011 NSQIP Datasets. Journal of Plastic Surgery and Hand Surgery, 48, 334-339. https://doi.org/10.3109/2000656X.2014.886582

[55] Nguyen, T., Costa, M.A., Vidar, E.N., Shahabi, A., Peric, M., Hernandez, A.M., Chan, L.S., Sener, S.F. and Wong, A. (2012) Effect of Immediate Reconstruction on Postmastectomy Surgical Site Infection. Annals of Surgery, 256, 326-333. https://doi.org/10.1097/SLA.0b013e3182602bb7

[56] Olsen, M.A., Nickel, K.B., Margenthaler, J.A., Wallace, A.E., Mines, D., Miller, J.P., Fraser, V.J. and Warren, D.K. (2015) Increased Risk of Surgical Site Infection among Breast-Conserving Surgery Re-Excisions. Annals of Surgical Oncology, 22, 2003-2009. https://doi.org/10.1245/s10434-014-4200-x

[57] Olsen, M.A., Nickel, K.B., Margenthaler, J.A., et al. (2016) Development of a Risk Prediction Model to Individualize Risk Factors for Surgical Site Infection after Mastectomy. Annals of Surgical Oncology, 23, 2471-2479. https://doi.org/10.1245/s10434-015-5083-1

[58] Olsen, M.A., Nickel, K.B., Fox, I.K., Margenthaler, J.A., Wallace, A.E. and Fraser, V.J. (2017) Comparison of Wound Complications after Immediate, Delayed, and Secondary Breast Reconstruction Procedures. JAMA Surgery, 152, e172338. https://doi.org/10.1001/jamasurg.2017.2338

[59] Ota, D., Fukuuchi, A., Iwahira, Y., Kato, T., Takeuchi, M., Okamoto, J., et al. (2014) Clinical Outcome of Reconstruction with Tissue Expanders for Patients with Breast Cancer and Mastectomy. Clinical Breast Cancer, 14, 339-345. https://doi.org/10.1016/j.clbc.2013.12.014

[60] Ota, D., Fukuuchi, A., Iwahira, Y., Kato, T., Takeuchi, M., Okamoto, J. and Nishi, T. 
(2016) Identification of Complications in Mastectomy with Immediate Reconstruction Using Tissue Expanders and Permanent Implants for Breast Cancer Patients. Breast Cancer, 23, 400-406. https://doi.org/10.1007/s12282-014-0577-4

[61] Peled, A.W., Itakura, K., Foster, R.D., Hamolsky, D., Tanaka, J., Ewing, C., et al. (2010) Impact of Chemotherapy on Postoperative Complications after Mastectomy and Immediate Breast Reconstruction. The Archives of Surgery, 145, 880-885. https://doi.org/10.1001/archsurg.2010.163

[62] Petersen, L., Carlson, K., Kopkash, K., Witt, T. and Madrigrano, A. (2017) Preoperative Antibiotics Do Not Reduce Postoperative Infections Following Needle-Localized Lumpectomy. The Breast Journal, 23, 49-51. https://doi.org/10.1111/tbj.12679

[63] Phillips, B.T., Fourman, M.S., Dagum, A.B., Huston, T.L., Ganz, J.C., Khan, S.U., et al. (2013) Results of a Prospective Randomized Clinical Trial Assessing Postoperative Antibiotic Use in Immediate Breast Reconstruction. Journal of the American College of Surgeons, 217, S88. https://doi.org/10.1016/j.jamcollsurg.2013.07.197

[64] Phillips, B.T., Fourman, M.S., Bishawi, M., Zegers, M., O’Hea, B.J., Ganz, J.C., Huston, T.L., Dagum, A.B., Khan, S.U. and Bui, D.T. (2016) Are Prophylactic Postoperative Antibiotics Necessary for Immediate Breast Reconstruction? Results of a Prospective Randomized Clinical Trial. Journal of the American College of Surgeons, 222, 1116-1124. https://doi.org/10.1016/j.jamcollsurg.2016.02.018

[65] Sinha, I., Pusic, A.L., Wilkins, E.G., Hamill, J.B., Chen, X., Kim, H.M., Guldbrandsen, G. and Chun, Y.S. (2017) Late Surgical-Site Infection in Immediate Implant-Based Breast Reconstruction. Plastic and Reconstructive Surgery, 139, 20-28. https://doi.org/10.1097/PRS.0000000000002839

[66] Sorkin, M., Qi, J., Kim, H.M., et al. (2017) Acellular Dermal Matrix in Immediate Expander/Implant Breast Reconstruction: A Multicenter Assessment of Risks and Benefits. Plastic and Reconstructive Surgery, 140, 1091-1100. https://doi.org/10.1097/PRS.0000000000003842

[67] Tanner, J., Khan, D., Ball, J., Aplin, C., Pickard, J. and Bankart, J. (2011) The Rate, Risk Factors and Cost of Surgical Site Infections in Primary Breast Surgery. Journal of Infection Prevention, 12, 204-209. https://doi.org/10.1177/1757177411411123

[68] Teija-Kaisa, A., Eija, M., Marja, S. and Outi, L. (2013) Risk Factors for Surgical Site Infection in Breast Surgery. Journal of Clinical Nursing, 22, 948-957.

https://doi.org/10.1111/jocn.12009

[69] Townley, W.A., Baluch, N., Bagher, S., Maass, S.W.M.C., O’Neill, A., Zhong, T., et al. (2015) A Single Pre-Operative Antibiotic Dose Is as Effective as Continued Antibiotic Prophylaxis in Implant-Based Breast Reconstruction: A Matched Cohort Study. Journal of Plastic, Reconstructive \& Aesthetic Surgery, 68, 673-678. https://doi.org/10.1016/j.bjps.2014.12.041

[70] Vardanian, A.J., Clayton, J.L., Roostaeian, J., Shirvanian, V., Da Lio, A., Lipa, J.E., et al. (2011) Comparison of Implant-Based Immediate Breast Reconstruction with and without Acellular Dermal Matrix. Plastic and Reconstructive Surgery, 128, 403e-410e. https://doi.org/10.1097/PRS.0b013e31822b6637

[71] Vieira, L.F., De Melo Neto, A.F., Schio, M.R., De Oliveira, J.A., Almeida, C.L. and Ferraz, A.A. (2016) Controversies in Reduction Mammoplasty: Being A "Clean" Operation, Does It Mandate Antibiotic Prophylaxis? Surgical Infections, 17, 596-600. https://doi.org/10.1089/sur.2016.072

[72] Winocour, S., Martinez-Jorge, J., Habermann, E., Thomsen, K. and Lemaine, V. (2015) Early Surgical Site Infection Following Tissue Expander Breast Reconstruction with or without Acellular Dermal Matrix: National Benchmarking Using Na- 
tional Surgical Quality Improvement Program. Archives of Plastic Surgery, 42, 194-200. https://doi.org/10.5999/aps.2015.42.2.194

[73] Yang, S., Liu, G., Tang, D. and Cai, D. (2017) Evaluation Intravenous Drip Cephazolin Prophylaxis of Breast Cancer Surgery Site Infection. Journal of Craniofacial Surgery, 28, e527-e531. https://doi.org/10.1097/SCS.0000000000003780

[74] Yetim, I., Özkan, O.V., Dervişoglu, A., Erzurumlu, K. and Canbolant, E. (2010) Effect of Local Gentamicin Application on Healing and Wound Infection in Patients with Modified Radical Mastectomy: A Prospective Randomized Study. Journal of International Medical Research, 38, 1442-1447. https://doi.org/10.1177/147323001003800426

[75] Chattha, A., Bucknor, A., Kamali, P., Van Veldhuisen, C.L., Flecha-Hirsch, R., Sharma, R., Tobias, A.M., Lee, B.T. and Lin, S.J. (2017) Comparison of Risk Factors and Complications in Patients by Stratified Mastectomy Weight: An Institutional Review of 1041 Consecutive Cases. Journal of Surgical Oncology, 116, 811-818. https://doi.org/10.1002/jso.24753

[76] Cooney, C.M., Sebai, M.E., Ogbuagu, O., Devulapalli, C., Manahan, M.A. and Rosson, G.D. (2016) Matching Procedures at the Time of Immediate Breast Reconstruction: An American College of Surgeons National Surgical Quality Improvement Program Study of 24,191 Patients. Plastic and Reconstructive Surgery, 138, 959e-968e. https://doi.org/10.1097/PRS.0000000000002739

[77] Cordeiro, E., Jackson, T. and Cil, T. (2016) Same-Day Major Breast Cancer Surgery is Safe: An Analysis of Short-Term Outcomes Using NSQIP Data. Annals of Surgical Oncology, 23, 2480-2486. https://doi.org/10.1245/s10434-016-5128-0

[78] De Oliveira, M.M.F., De Rezende, L.F., Do Amaral, M.T.P., Pinto E Silva, M.P., Morais, S.S. and Costa Gurgel, M.S. (2014) Manual Lymphatic Drainage versus Exercise in the Early postoperative Period for Breast Cancer. Physiotherapy Theory and Practice, 30, 384-389. https://doi.org/10.3109/09593985.2013.876695

[79] Dieterich, M., Reimer, T., Kundt, G., Stubert, J. and Gerber, B. (2013) The Role of Hydroxyethyl Starch in Preventing Surgical-Site Infections and Nipple Necrosis in Patients Undergoing Reduction Mammoplasty: A Prospective Case-Control Study of 334 Patients. Aesthetic Plastic Surgery, 37, 554-560.

https://doi.org/10.1007/s00266-013-0113-5

[80] Gil-Londoño, J.-C., Nagles-Pelaez, J.-A., Maya-Salazar, W.-A., Madrid, J., Maya-Restrepo, M.-A., Agudelo-Pérez, R.-A., et al. (2016) Surgical Site Infection after Breast Cancer Surgery at 30 Days and Associated Factors. Infectio, 21, 96-101. https://doi.org/10.1016/j.infect.2016.04.003

[81] Giordano, S., Peltoniemi, H., Lilius, P. and Salmi, A. (2013) Povidone-Iodine Combined with Antibiotic Topical Irrigation to Reduce Capsular Contracture in Cosmetic Breast Augmentation: A Comparative Study. Aesthetic Surgery Journal, 33, 675-680. https://doi.org/10.1177/1090820X13491490

[82] Golfam, F., Golfam, P., Golfam, B., Mortaz, S. and Pahlevani, P. (2011) PP-036 Effects of Supplemental Oxygen for Prevention of Wound Infection after Breast Surgery. International Journal of Infectious Diseases, 15, S55. https://doi.org/10.1016/S1201-9712(11)60189-6

[83] Gülçelik, M.A., Doğan, L., Karaman, N., Turan, M., Kahraman, Y.S., Akgül, G.G. and Özaslan, C. (2017) Intraoperative Boost Radiation Effects on Early Wound Complications in Breast Cancer Patients Undergoing Breast-Conserving Surgery. Turkish Journal of Medical Sciences, 47, 1185-1190.

https://doi.org/10.3906/sag-1605-48 
[84] Mittal, P., Kumar, A., Kaur, S., Pandove, P.K., Singla, R.L. and Singh, J. (2017) A Comparative Study of the Use of Harmonic Scalpel versus Unipolar Cautery in Modified Radical Mastectomy. Nigerian Journal of Surgery, 23, 20-25. https://doi.org/10.4103/1117-6806.199962

[85] Parikh, R., Pollock, D., Sharma, J. and Edwards, J. (2016) Is There Room for Prevention? Examining the Effect of Outpatient Facility Type on the Risk of Surgical Site Infection. Infection Control \& Hospital Epidemiology, 37, 1179-1185. https://doi.org/10.1017/ice.2016.146

[86] Pellino, G., Sciaudone, G., Candilio, G., De Fatico, G.S., Landino, I., Della Corte, A., et al. (2014) Preventive NPWT Over Closed Incisions in General Surgery: Does Age Matter? International Journal of Surgery, 12, S64-S68. https://doi.org/10.1016/j.ijsu.2014.08.378

[87] Pettke, E., Ilonzo, N., Ayewah, M., Tsantes, S., Estabrook, A. and Ma, A.M.T. (2016) Short-Term, Postoperative Breast Cancer Outcomes in Patients with Advanced Age. The American Journal of Surgery, 212, 677-681. https://doi.org/10.1016/j.amjsurg.2016.06.007

[88] Santosa, K.B., Chen, X., Qi, J., Ballard, T.N., Kim, H.M., Hamill, J.B., Bensenhaver, J.M., Pusic, A.L. and Wilkins, E.G. (2016) Postmastectomy Radiation Therapy and Two-Stage Implant-Based Breast Reconstruction: Is There a Better Time to Irradiate? Plastic and Reconstructive Surgery, 138, 761-769. https://doi.org/10.1097/PRS.0000000000002534

[89] Williams, N., Sweetland, H., Goyal, S., Ivins, N. and Leaper, D.J. (2011) Randomized Trial of Antimicrobial-Coated Sutures to Prevent Surgical Site Infection after Breast Cancer Surgery. Surgical Infections, 12, 469-474.

https://doi.org/10.1089/sur.2011.045

[90] Breuing, K., Butler, C.E., Ferzoco, S., Franz, M., Hultman, C.S., Kilbridge, J.F., et al. (2010) Incisional Ventral Hernias: Review of the Literature and Recommendations Regarding the Grading and Technique of Repair. Surgery, 148, 544-558. https://doi.org/10.1016/j.surg.2010.01.008

[91] Baucom, R.B., Ousley, J., Beveridge, G.B., Phillips, S.E., Pierce, R.A., Holzman, M.D., Sharp, K.W., Nealon, W.H. and Poulose, B.K. (2016) Cancer Survivorship: Defining the Incidence of Incisional Hernia after Resection for Intra-Abdominal Malignancy. Annals of Surgical Oncology, 23, 764-771. https://doi.org/10.1245/s10434-016-5546-Z

[92] DeBord, J., Novitsky, Y., Fitzgibbons, R., Miserez, M. and Montgomery, A. (2018) SSI, SSO, SSE, SSOPI: The Elusive Language of Complications in Hernia Surgery. Hernia, 22, 737-738. https://doi.org/10.1007/s10029-018-1813-1

[93] Indelicato, D., Grobmyer, S.R., Newlin, H., et al. (2007) Association between Operative Closure Type and Acute Infection, Local Recurrence, and Disease Surveillance in Patients Undergoing Breast Conserving Therapy for Early-Stage Breast Cancer. Surgery, 141, 645-653. https://doi.org/10.1016/j.surg.2006.12.011

[94] Chan, M.Y.P., Ho, S.Y.M., Thambiah, M., Seah, D.W., Chen, J.C., et al. (2017) Immediate Breast Reconstruction Does Not Delay Adjuvant Chemotherapy nor affect Clinical Outcome. Breast Cancer. Current Research, 2, 118.

https://doi.org/10.4172/2572-4118.1000118

[95] Valente, S.A., Liu, Y., Upadhyaya, S., Tu, C. and Pratt, D.A. (2019) The Effect of Wound Complications Following Mastectomy with Immediate Reconstruction on Breast Cancer Recurrence. The American Journal of Surgery, 217, 514-518. https://doi.org/10.1016/j.amjsurg.2018.10.028 
[96] Olsen, M.A., Chu-Ongsakul, S., Brandt, K.E., Dietz, J.R., Mayfield, J. and Fraser, V.J. (2008) Hospital-Associated Costs Due to Surgical Site Infection after Breast Surgery. The Archives of Surgery, 143, 53-60.

https://doi.org/10.1001/archsurg.2007.11 


\section{Supplemental Files}

Table S1. MINORS grading of studies included in the meta-analysis.

\begin{tabular}{|c|c|c|c|c|c|c|c|c|c|c|c|c|c|c|}
\hline Study ID & & & & Non-co & mparativ & & & & & & mparativ & & & \\
\hline 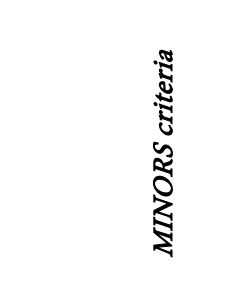 & 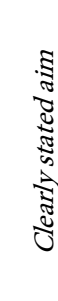 & 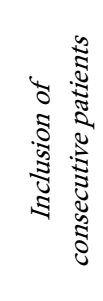 & 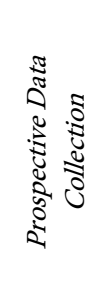 & 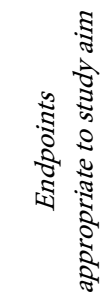 & 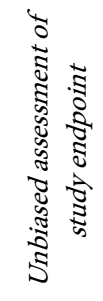 & 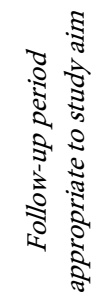 & 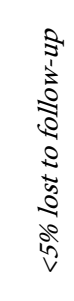 & 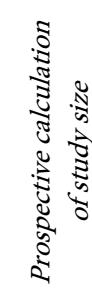 & 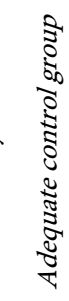 & 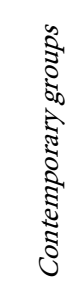 & 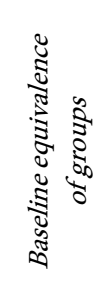 & 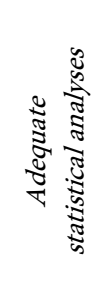 & $\begin{array}{l}\text { Total } \\
\text { Score }\end{array}$ & Study design \\
\hline \multicolumn{15}{|c|}{ Quantitative Analysis } \\
\hline Angarita 2011 [26] & 2 & 2 & 2 & 2 & 0 & 2 & 2 & 1 & & & & & $13 / 16$ & $\begin{array}{l}\text { Retrospective } \\
\text { cohort }\end{array}$ \\
\hline Avashia 2013 [27] & 2 & 2 & 1 & 2 & 0 & 2 & 2 & 1 & & & & & $12 / 16$ & $\begin{array}{l}\text { Retrospective } \\
\text { cohort }\end{array}$ \\
\hline Bowen 2017 [28] & 2 & 2 & 2 & 2 & 0 & 2 & 2 & 2 & & & & & $14 / 16$ & $\begin{array}{l}\text { Retrospective } \\
\text { cohort }\end{array}$ \\
\hline Cabaluna 2013 [29] & 2 & 2 & 2 & 2 & 2 & 2 & 2 & 2 & 2 & 2 & 2 & 2 & $24 / 24$ & RCT \\
\hline Chung 2015 [30] & 2 & 2 & 1 & 2 & 0 & 2 & 2 & 2 & & & & & $13 / 16$ & $\begin{array}{l}\text { Retrospective } \\
\text { cohort }\end{array}$ \\
\hline Clayton 2012 [31] & 2 & 2 & 1 & 2 & 0 & 1 & 2 & 2 & & & & & $12 / 16$ & $\begin{array}{l}\text { Retrospective } \\
\text { cohort }\end{array}$ \\
\hline Crawford 2016 [32] & 2 & 2 & 2 & 2 & 0 & 2 & 2 & 2 & & & & & $14 / 16$ & $\begin{array}{l}\text { Retrospective } \\
\text { cohort }\end{array}$ \\
\hline Davis 2013 [33] & 2 & 2 & 2 & 2 & 0 & 2 & 2 & 2 & & & & & $14 / 16$ & $\begin{array}{l}\text { Retrospective } \\
\text { cohort }\end{array}$ \\
\hline Decker 2012 [34] & 2 & 2 & 2 & 2 & 0 & 2 & 2 & 2 & & & & & $14 / 16$ & $\begin{array}{l}\text { Prospective } \\
\text { cohort }\end{array}$ \\
\hline Degnim 2013 [35] & 2 & 2 & 2 & 2 & 2 & 2 & 2 & 2 & 2 & 2 & 2 & 2 & $24 / 24$ & RCT \\
\hline Degnim 2014 [36] & 2 & 2 & 2 & 2 & 2 & 2 & 2 & 2 & 2 & 2 & 2 & 2 & $24 / 24$ & RCT \\
\hline Dikmans 2017 [37] & 2 & 2 & 2 & 1 & 2 & 2 & 2 & 2 & 2 & 2 & 2 & 2 & $23 / 24$ & RCT \\
\hline Drury 2016 [38] & 2 & 2 & 2 & 2 & 0 & 2 & 2 & 2 & & & & & $14 / 16$ & $\begin{array}{l}\text { Retrospective } \\
\text { cohort }\end{array}$ \\
\hline Edwards 2014 [39] & 2 & 2 & 2 & 2 & 0 & 1 & 2 & 2 & & & & & $13 / 16$ & $\begin{array}{l}\text { Retrospective } \\
\text { cohort }\end{array}$ \\
\hline Franchelli 2012 [40] & 2 & 2 & 1 & 1 & 0 & 2 & 2 & 1 & 2 & 2 & 2 & 0 & $17 / 24$ & RCT \\
\hline Fraser 2016 [41] & 2 & 2 & 2 & 2 & 0 & 2 & 2 & 2 & & & & & $14 / 16$ & $\begin{array}{l}\text { Retrospective } \\
\text { cohort }\end{array}$ \\
\hline Gao 2010 [42] & 2 & 2 & 2 & 2 & 0 & 1 & 2 & 1 & & & & & $12 / 16$ & $\begin{array}{l}\text { Retrospective } \\
\text { cohort }\end{array}$ \\
\hline Gulluoglu 2013 [43] & 2 & 2 & 2 & 2 & 2 & 2 & 2 & 2 & 2 & 2 & 1 & 2 & $23 / 24$ & RCT \\
\hline Gust 2013 [44] & 2 & 2 & 2 & 2 & 0 & 2 & 2 & 2 & & & & & $14 / 16$ & $\begin{array}{l}\text { Retrospective } \\
\text { cohort }\end{array}$ \\
\hline
\end{tabular}




\section{Continued}

\begin{tabular}{|c|c|c|c|c|c|c|c|c|c|c|c|c|c|c|}
\hline Hadad 2017 [45] & 2 & 2 & 2 & 2 & 0 & 2 & 2 & 2 & & & & & $14 / 16$ & $\begin{array}{l}\text { Retrospective } \\
\text { cohort }\end{array}$ \\
\hline Hillam 2017 [46] & 2 & 2 & 2 & 2 & 0 & 2 & 2 & 2 & & & & & $14 / 16$ & $\begin{array}{l}\text { Retrospective } \\
\text { cohort }\end{array}$ \\
\hline Khan 2010 [47] & 2 & 2 & 2 & 2 & 0 & 0 & 2 & 1 & & & & & $11 / 16$ & $\begin{array}{l}\text { Retrospective } \\
\text { cohort }\end{array}$ \\
\hline Lewin 2015 [48] & 2 & 2 & 2 & 2 & 1 & 2 & 2 & 2 & 2 & 2 & 2 & 2 & $23 / 24$ & RCT \\
\hline Leyngold 2012 [49] & 2 & 2 & 2 & 1 & 0 & 0 & 2 & 2 & & & & & $11 / 16$ & $\begin{array}{l}\text { Retrospective } \\
\text { cohort }\end{array}$ \\
\hline Liu 2011 [50] & 2 & 2 & 2 & 1 & 0 & 2 & 2 & 2 & & & & & $13 / 16$ & $\begin{array}{l}\text { Retrospective } \\
\text { cohort }\end{array}$ \\
\hline Liu 2012 [51] & 2 & 2 & 2 & 2 & 0 & 0 & 2 & 2 & & & & & $12 / 16$ & $\begin{array}{l}\text { Retrospective } \\
\text { cohort }\end{array}$ \\
\hline McCullough 2014 [52] & 2 & 2 & 2 & 2 & 0 & 1 & 2 & 1 & & & & & $12 / 16$ & $\begin{array}{l}\text { Retrospective } \\
\text { cohort }\end{array}$ \\
\hline Mirzabeigi 2012 [53] & 2 & 2 & 2 & 1 & 0 & 2 & 2 & 1 & & & & & $12 / 16$ & $\begin{array}{l}\text { Retrospective } \\
\text { cohort }\end{array}$ \\
\hline Nelson 2014 [54] & 2 & 2 & 2 & 2 & 0 & 2 & 2 & 1 & & & & & $13 / 16$ & $\begin{array}{l}\text { Retrospective } \\
\text { cohort }\end{array}$ \\
\hline Nguyen 2012 [55] & 2 & 2 & 2 & 2 & 0 & 2 & 2 & 2 & & & & & $14 / 16$ & $\begin{array}{l}\text { Retrospective } \\
\text { cohort }\end{array}$ \\
\hline Olsen 2015 [56] & 2 & 2 & 2 & 2 & 0 & 2 & 2 & 2 & & & & & $14 / 16$ & $\begin{array}{l}\text { Retrospective } \\
\text { cohort }\end{array}$ \\
\hline Olsen 2016 [57] & 2 & 2 & 2 & 2 & 0 & 2 & 2 & 2 & & & & & $14 / 16$ & $\begin{array}{l}\text { Retrospective } \\
\text { cohort }\end{array}$ \\
\hline Olsen 2017 [58] & 2 & 2 & 1 & 2 & 0 & 2 & 2 & 1 & & & & & $12 / 16$ & $\begin{array}{l}\text { Retrospective } \\
\text { cohort }\end{array}$ \\
\hline Ota 2014 [59] & 2 & 2 & 2 & 2 & 0 & 2 & 2 & 1 & & & & & $13 / 16$ & $\begin{array}{l}\text { Retrospective } \\
\text { cohort }\end{array}$ \\
\hline Ota $2016[60]$ & 2 & 2 & 2 & 2 & 0 & 2 & 2 & 2 & & & & & $14 / 16$ & $\begin{array}{l}\text { Retrospective } \\
\text { cohort }\end{array}$ \\
\hline Peled 2010 [61] & 2 & 2 & 2 & 2 & 0 & 2 & 2 & 1 & & & & & $13 / 16$ & $\begin{array}{l}\text { Retrospective } \\
\text { cohort }\end{array}$ \\
\hline Petersen 2016 [62] & 2 & 2 & 2 & 1 & 0 & 2 & 2 & 1 & & & & & $12 / 16$ & $\begin{array}{l}\text { Retrospective } \\
\text { cohort }\end{array}$ \\
\hline Phillips 2013 [63] & 2 & 2 & 2 & 2 & 0 & 2 & 2 & 1 & 2 & 2 & 2 & 1 & $20 / 24$ & RCT \\
\hline Phillips 2016 [64] & 2 & 2 & 2 & 2 & 0 & 2 & 2 & 1 & 2 & 2 & 2 & 1 & $20 / 24$ & RCT \\
\hline Sinha 2017 [65] & 2 & 2 & 2 & 2 & 0 & 2 & 2 & 2 & & & & & $14 / 16$ & $\begin{array}{l}\text { Prospective } \\
\text { cohort }\end{array}$ \\
\hline Sorkin 2017 [66] & 2 & 2 & 2 & 2 & 0 & 2 & 1 & 2 & & & & & $13 / 16$ & $\begin{array}{l}\text { Prospective } \\
\text { cohort }\end{array}$ \\
\hline Tanner 2011 [67] & 2 & 2 & 2 & 2 & 0 & 2 & 2 & 2 & & & & & $14 / 16$ & $\begin{array}{l}\text { Prospective } \\
\text { cohort }\end{array}$ \\
\hline
\end{tabular}




\section{Continued}

\begin{tabular}{|c|c|c|c|c|c|c|c|c|c|c|c|c|c|c|}
\hline Teija-Kaisa 2012 [68] & 2 & 2 & 2 & 2 & 0 & 2 & 2 & 2 & & & & & $14 / 16$ & $\begin{array}{l}\text { Retrospective } \\
\text { cohort }\end{array}$ \\
\hline Townley 2015 [69] & 2 & 2 & 2 & 2 & 0 & 2 & 2 & 2 & & & & & $14 / 16$ & $\begin{array}{l}\text { Retrospective } \\
\text { cohort }\end{array}$ \\
\hline Vardanian 2011 [70] & 2 & 2 & 2 & 1 & 0 & 2 & 2 & 2 & & & & & $13 / 16$ & $\begin{array}{l}\text { Retrospective } \\
\text { cohort }\end{array}$ \\
\hline Vieira 2016 [71] & 2 & 2 & 2 & 2 & 2 & 2 & 2 & 1 & 2 & 2 & 2 & 1 & $22 / 24$ & RCT \\
\hline Winocour 2015 [72] & 2 & 2 & 2 & 2 & 0 & 2 & 2 & 2 & & & & & $14 / 16$ & $\begin{array}{l}\text { Retrospective } \\
\text { cohort }\end{array}$ \\
\hline Yang 2017 [73] & 2 & 2 & 2 & 2 & 0 & 0 & 2 & 2 & & & & & $12 / 16$ & $\begin{array}{l}\text { Retrospective } \\
\text { cohort }\end{array}$ \\
\hline \multicolumn{15}{|l|}{ Qualitative Analysis } \\
\hline Chattha 2017 [75] & 2 & 2 & 2 & 2 & 0 & 2 & 2 & 2 & & & & & $14 / 16$ & $\begin{array}{l}\text { Retrospective } \\
\text { cohort }\end{array}$ \\
\hline Cooney 2016 [76] & 2 & 2 & 2 & 2 & 0 & 2 & 2 & 2 & & & & & $14 / 16$ & $\begin{array}{l}\text { Retrospective } \\
\text { cohort }\end{array}$ \\
\hline Cordeiro 2016 [77] & 2 & 2 & 2 & 2 & 0 & 2 & 2 & 2 & & & & & $14 / 16$ & $\begin{array}{l}\text { Retrospective } \\
\text { cohort }\end{array}$ \\
\hline de Oliveira 2014 [78] & 2 & 2 & 2 & 2 & 2 & 2 & 2 & 2 & 2 & 2 & 2 & 1 & $23 / 24$ & $\begin{array}{l}\text { Non-randomised } \\
\text { controlled trial }\end{array}$ \\
\hline Dieterich 2013 [79] & 2 & 2 & 2 & 2 & 0 & 2 & 2 & 2 & & & & & $14 / 16$ & $\begin{array}{l}\text { Prospective } \\
\text { cohort }\end{array}$ \\
\hline Gil-Londoño 2017 [80] & 2 & 2 & 2 & 2 & 0 & 2 & 2 & 2 & & & & & $14 / 16$ & $\begin{array}{l}\text { Prospective } \\
\text { cohort }\end{array}$ \\
\hline Giordano 2013 [81] & 2 & 2 & 2 & 1 & 0 & 2 & 2 & 1 & & & & & $12 / 16$ & $\begin{array}{l}\text { Retrospective } \\
\text { cohort }\end{array}$ \\
\hline Golfam 2011 [82] & 2 & 2 & 2 & 2 & 2 & 2 & 2 & 1 & 2 & 2 & 0 & 1 & $20 / 24$ & RCT \\
\hline Gülçelık 2017 [83] & 2 & 2 & 2 & 2 & 0 & 0 & 2 & 1 & & & & & $11 / 16$ & $\begin{array}{l}\text { Retrospective } \\
\text { cohort }\end{array}$ \\
\hline Mittal 2017 [84] & 2 & 2 & 2 & 1 & 0 & 2 & 2 & 1 & 2 & 2 & 2 & 1 & $19 / 24$ & $\mathrm{RCT}$ \\
\hline Parikh 2016 [85] & 2 & 2 & 2 & 2 & 0 & 2 & 2 & 2 & & & & & $14 / 16$ & $\begin{array}{l}\text { Retrospective } \\
\text { cohort }\end{array}$ \\
\hline Pellino 2014 [86] & 2 & 2 & 2 & 2 & 0 & 2 & 2 & 1 & 2 & 2 & 2 & 1 & $20 / 24$ & RCT \\
\hline Pettke 2016 [87] & 2 & 2 & 2 & 2 & 0 & 2 & 2 & 2 & & & & & $14 / 16$ & $\begin{array}{l}\text { Retrospective } \\
\text { cohort }\end{array}$ \\
\hline Santosa 2016 [88] & 2 & 2 & 2 & 2 & 0 & 2 & 2 & 2 & & & & & $14 / 16$ & $\begin{array}{l}\text { Retrospective } \\
\text { cohort }\end{array}$ \\
\hline Williams 2011 [89] & 2 & 2 & 2 & 2 & 2 & 2 & 2 & 2 & 2 & 2 & 2 & 2 & $24 / 24$ & $\mathrm{RCT}$ \\
\hline
\end{tabular}

Table S2. Characteristics of studies included in the meta-analysis.

https://data.mendeley.com/datasets/g46xn6x9n5/draft?a=b6b121da-b2a7-4b7d-80c7-50d d0f137ffb 


\section{Abbreviations}

ADM: Acellular Dermal Matrix,

ALND: Axillary Lymph Node Dissection,

AMP: Antimicrobial Prophylaxis,

ASA: American Society of Anesthesiologists Physical Classification System,

BCS: Breast Conserving Surgery,

BMI: Body Mass Index,

BR: Breast Reconstruction,

CDC: Centers for Disease Control and Prevention Guideline for Prevention of Surgical Site Infections,

CI: Confidence Interval,

DCIS: Ductal Carcinoma in Situ,

DR: Delayed Reconstruction,

ECOG: Eastern Cooperative Oncology Group performance status,

IBBR: Implant-Based Breast Reconstruction,

IBR: Immediate Breast Reconstruction,

IORT: Intraoperative Radiotherapy,

IR: Immediate Reconstruction,

ITEBR: Immediate Tissue Expander-Based Breast Reconstruction,

MINORS: Methodological Index for Nonrandomised Studies,

MLD: Manual Lymphatic Drainage,

MRM: Modified Radical Mastectomy,

NNIS: National Nosocomial Infection Surveillance,

NPWT: Negative Pressure Wound Therapy,

OR: Odds Ratio,

RCT: Randomised Controlled Trial,

PI: Permanent Implant,

RR: Risk Ratio,

SLNB: Sentinel Lymph Node Biopsy,

SR: Subsequent Reconstruction,

SSI: Surgical Site Infection,

SSO: Surgical Site Occurrence,

TE: Tissue Expander,

TEBR: Tissue Expander-Based Reconstruction,

TM: Total Mastectomy,

TNM: Tumour Node Metastasis classification,

WLE: Wide Local Excision. 